NASA Technical Memorandum 83556

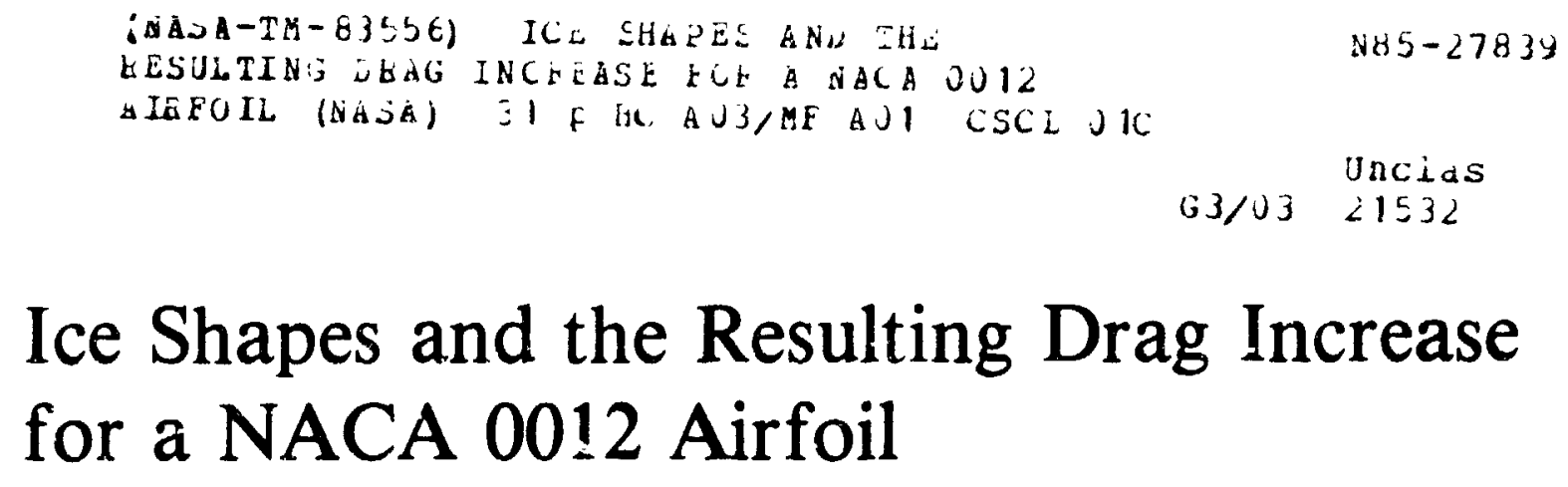

\section{Ice Shapes and the Resulting Drag Increase for a NACA 0012 Airfoil}

William Olsen, Robert Shaw, and James Newton

Lewis Research Center

Cleveland, Ohio

Prepared for the

Twenty-second Aerospace Sciences Meeting sponsored by the American Institute of Aeronautics and Astronautics Reno, Nevada, January 9--12, 1984

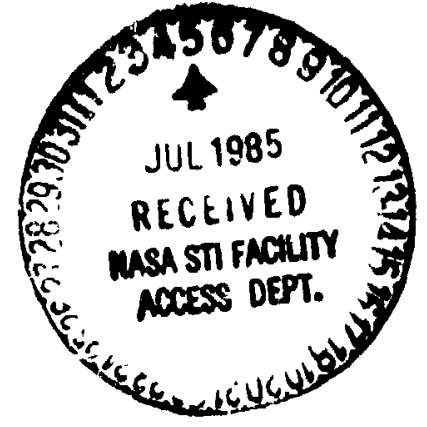


ICE SHAPES AND THE RESULTING DRAG INCREASE FOR A NACA 0012 AIRFOIL

\author{
wilitiam oitsen, Kobert snaw, and James Newton \\ National Aeronautics and Space Administration \\ Lewis Research Center \\ Cleveland, ohio 44135
}

\title{
SUMMARY
}

Experimental measurements of the tce shapes and resulting drag increase were measured in the NASA Icing Research Tunnel. The measurements were made over a large range of conditions (e.g., alrspeed and temperature, the drep size and liquid water content of the cloud, and the angle of attack of the airfolli.

Additional results are given which are helpful in understanding the ice structure and the way it forms, and in improving the ice accretion modeling theorles. There are data on the ice surface roughness, on the effect of the ice shaue on the local droplet catch, and on the relative importance of various parts of the ice shape on the drag increase. Experimental repeatability is also discussed.

\section{INTRODUCTION}

Part of the NASA icing research program involves the development of analyses to predict the ice accretion on alrfolls and the resulting aerodynamic penalty. Extensive experimerital data for ice accretion and the resulting drag are being obtained for several representative alrfoils to add to the existing data base. The emphasis is on airfolls of current interest. The airfoll covered in detall in this paper is trie NACA 0012 alrfoll.

Detalled measurements were made of the fce accretion and the resulting drag in the NASA Lewls Icing Research Tunnel (IRT). These data were obtalned over a range of alr temperature, airspeed airfoll angle of attack, spray time, liquid water content and drop size. The results can be used in tre development of computer codes to predict the ice accretion and resulting drag. The drag results are compared to the existing correlation (ref. 1). Additional experiments were performed to improve our undcrstanding of icing, such as: the ice structure, surface roughness, the effect of ice shape on the droplet catch, and what part of the ice shape is important.

\section{APPARATUS AND PROCEDURE}

The AACA 0012 alrfoll model, the Icing Research Tunnel (IRT), and the instrumertation used to measure the drag coefficlent are discussed in this section.

\section{Description of the IRT}

Tire IRT is a closed loop low speed refrlgerated wind tunnel. Its test section (fig. 1), is $3.33 \mathrm{~m} \mathrm{high}$ and $2.74 \mathrm{~m}$ wide. The airspeed in the test 
section can be varled from 30 to $480 \mathrm{~km} / \mathrm{hr}$, and the total temperature can be varted from above $\mathrm{O}^{\circ} \mathrm{C}$ down to about $-30^{\circ} \mathrm{C}$. According to the present cal1bration, the icing ciouo issuirig from 77 air atomizing nozzles can produce a drop size range of from below 10 to about 40 microns (volume median diameter, DVM). The liquid water content (LWC) in the test section can be varied from about 0.3 to $3.0 \mathrm{~g}^{3} \mathrm{~m}^{3}$. Not all combinations of DVM and LWC are possible at every alrspeed, The DV and LWC are set according to the present callibration by adjusting the air and water pressures to the spray nozzles. (The symobls used are defined in appendix A.) For detalls about the spray cloud calibration and a discussion of possible error sources, refer to reference 2 . The results in reference 2 indicate that the data reported herein should be free of any significant error.

\section{Atrfoll Model}

The alrfoll model used in this test program is a $0.53 \mathrm{~m}$ chord NACA 0012 airfoll. This model was mounted on the turntable in the IRT as shown in figures 1 and 2 . This arrangement permitted simple changes of the alrfoll angle-of-attack. The alrfoll used was a portion of a Urit helfcopter main rotor blade. Like all rotor blades, this alrfoll section had a small twist (one-half degree per foot of span), therefore the angle-of-attack of the airfoll was set at the center of the tunnel where the ice shape and section drag would be measured. As will be shown in the Results, the effects of using a production hellcopter atrfoll are negliglble.

\section{Drag Measurements}

The section drag at the center-span of the airfoll model was measured with a standard traversing wake survey probe. The pitot-static probe is shown positioned, downstream of the airfoll model in figure 1. The probe was two airfoll chords downstream of the alrfoll.

Drag wake surveys were taken only after the IRT spray cloud was turned off and the air was cloud reee. Whlle the spray system was on, the probe was retracted behind an ant1-1ced shleid to prevent lce accretion on the small unheated tip of the pitot-static probe. The probe support was anti-iced.

When activated, the wake survey probe automatically traversed the wake behind the wing. The speed of the traversing probe was adjusted before the test program so that no lags in the probe response extsted. For further detalls and a discussion of possible errors refer to appendix $B$, where it was concluded that there were no stgniflcant errors.

\section{Test Matrix and Procedure}

The test matrix is ilsted in table I. The tce shape and resulting drag coefficlent depend upon at least the following: the alrfoll shape and angle of attack, the air temperature and velocity, and the LWC and DVM of the cloud. With that number of parameters, only a sparse matrix of conditions and repeat conditions could be accomplished. 
The test procedure followed for most of the data runs is listed below:

(1) The model angle-of-attack ( $\alpha$ ) was set.

(2) The desired IRT afrspeed ( $V$ ) and total air temperature ( $T$ ) are set.

(3) The wind tunnel spray system was adjusted to the desired drop size (DVM) and liquid water content (LWC). If the spray time was to be short then the cloud setttings were pre-set, so that data were not affected by the time to adjust the cloud.

(4) After the desired spray time had eidpsed, the icing spray system was turned off.

(5) The tunnel was brought down to idle and the frost aft of the ice accretien was removed with a scraper. Tufts on the airfoll were also deiced.

(6) The wake survey probe was then traversed across the airfoil wake with the tunnel at the desired alrspeed.

(7) The tunnel was aga in brought to idle and the following were performed at the centerspan of the alrfoll: (a) a narrow slit was cut in the ice down to the alrfoll surface and the airfoll lce shape was traced on a plece of cardboard that was precut to fit the shape; (b) a template with a ruled grid was slipped into the ice slot and the ice was photographed from the same position relative to the airfoll; (c) the airfoll was then heated to obtain ice samples, which were placed in a freezer for later photographs of the ice structure and plaster casts of the ice sample.

(8) The airfoll was then totally cleaned free of ice and the next test was performed.

\section{RESULTS AND OISCUSSION}

This section primarlly contafris information about the effect of the icing parameters on the ice shape and resulting drag. The icing parameters are spray time, angle of attack, alrspeed, total temperature, drop size and liquid water content. There are data related to the quality of the experiment. In addition, there are other results which will be useful for the development of an improved ice accretion theory.

\section{Quality of the Data}

Most questions about the quality of the tunnel flow, the foing cloud and its calibration, and the drag measurements are discussed in reference 2 and appendix $B$. Reported in this section are data quality tests that are specific to this airfoll test and where an important conclusion is reached.

Comparison to published dry airfoll drag results. - Figure 3 shows how the drag coefficient for the dry alrfoll varied with angle of attack. Much of this dry alrfoll data came from the first run of every night of icing tests; this was used as a quality control reference for the drag data. Plotted on this figure is the published curve fit of data measured in aerodynamic wind 
tunnels for smooth 0012 airfo11s (ref. 3). A band is shown to account for the Reynold's number range of the dry alrfull data $\left(2 \times 10^{6}<\operatorname{Re}<3.2 \times 10^{6}\right)$. This good agreement suggests that concerns about using a section of a production helicopter rotor blade are unfounded. The wake survey probe measurements are also qualifled by this good agreement.

Repeatability of the dry afrfoll drag measurements. - Twenty seven repeat measurements of the drag coef 1 clent, $C_{D}$, were made with the dry 0012 alrfoll at a $4^{\circ}$ angle of attack curing the course of the experimental program. The average value of the drag coefficlent was 0.00814 . The percent varlation 1 of that data was 7.7 percent of the average value. That kind of scatter is typical of wind tunnel data.

Repeatablilty of the ice shapes and drag. - Figure 4(a) shows the repeatabllity of the ice shape and resulting drag coefficient for a typical rime ice shape accreted at $-26{ }^{\circ} \mathrm{C}$. The ice shapes and resulting drag coefficients repeat quite well; the scatter in the drag coefficient is comparable to the scatter observed with the dry airfoll data. Figure $4(\mathrm{~b})$ is a simflar rime ice repeatabllity comparison for a different icing condition. The rime ice shape and drag coefficient repeated well again. The percent vartations for both ets of $C_{D}$ data is about \pm 5 percent, which is close to the percent variation noted for the clean airfoll data.

Simtlar comparisons are made in figures 5(a) and (b) for two glaze ice shapes. There is a much larger variation in the ice shapes and drag coefficlent for one case on each figure. The percent varlations for both sets of $C_{D}$ data is about \pm 15 percent of the average values of $C_{D}$. This is much larger than the percent variation noted for the rime shapes or for the clean airfoll. Poor repeats have also been noted in other airfoll tests with glaze ice. No certain explanation for the poor repeatabllity of glaze lce shapes is avallable at this time.

\section{Effect of Angle of Attack}

Flgure 6(a) shows how the section drag coefficlent varies with angle of attack for one ice shape; a typical rime ice shape that was accreted $3 t$ a $4^{\circ}$ angle of attack. The drag measured at several angles for the clean airfoil is also plotted in figure $6(a)$. The drag is at least 50 percellt higher than the drag for the clean airfoll.

Figure $6(b)$ contains a simflar drag-angie sweep, except that the ice is a severe glaze ice shape. This glaze tce shape increased the drag cuefficient considerably; about four times larger than the clean alrfoll drag coefficlent. Above an angle of about $6^{\circ}$, the flow over the entire upper (suction) surface separated, as evidenced by tufts along the surface of the airfoll. Therefore, subsequent icing tests in this program were generally limited to less accretion time and to smailer angles in order to avold bad separation. with glaze tce.

$1_{\text {percent variation }}=\left(\frac{\text { Standard deviation of } C_{D} \text { data }}{\text { Average value of } C_{D}}\right) \times 100$ 
In figures $7(a)$ and (b) the ice accretion at different angles of attack is shown. The effect of angle of attack upon the ice shape and the resulting orag is shown on figure $7(a)$ for an icing condition that produces rime ice. Figure $7(b)$ is similar but the icing condition produced glaze ice. In this case only weak separation occurred at the $8^{\circ}$ angle. The clean airfoll dragangle sata are also plotted in figures $7(a)$ and (b) for comparison.

\section{Effect of Accretion Time}

The effect of the accretion time on the ice shape is shown on figure 8 . The ice was accreted at several angles; each for two icing conditions. Cases $A, B$, and $C$ share the same icing condition, which produces glaze ice. Each case is at a different angle of attack and involves as many as three sprays at different accretion times $(2,5$, and $15 \mathrm{~min})$. Cases $D, E$, and $F$ are similar, except that the icing condition for these 3 cases produces a rime type of ice. please note that a 11 accretion times reported herein should be corrected (reduced by $1 / 4 \mathrm{~min}$ ) to account for the time it takes the cloud to attain a steady value.

The ice shapes clearly show the fce accretion history (i.e., growth rings) starting from the initial dry alrfoll out to a 15 min growth. Notice that the horns in cases $A$ and $B$ are starting to show in the 5 min ice shape, but not in the 2 min shape.

The drag data for these cases are not reported here. These data were taken early in the program before it was realized that the frost buildup on the aft surfaces of the airfoll must be removed in order to achieve accurate drag measurements that are representative of flight. In natural icing filghts there is no frost bul?dup. Appendix $b$ describes the results of an experiment to determine the effect of frost on the drag measurement.

\section{Effect of Temperature}

Temperature has the greatest effect upon the ice shape and the lce structure. The photographs on figure 9 show the ice, on both sides of the airfo11, at one temperature. Figure 10(a) shows how the lce shape changes with increased temperature for two lcing conditions. The lce shape tracing at $209 \mathrm{~km} / \mathrm{hr}$ and a total temperature of $-15{ }^{\circ} \mathrm{C}$ corresponds to the photographs in figure 9. The ice at the coldest temperature $\left(-26^{\circ} \mathrm{C}\right)$ is white and pointed at the stagnation point, which is typical of rime ice. As the temperature increases the shape gradually changes to a horn shaped glaze ice. When the total temperature is very close to $0{ }^{\circ} \mathrm{C}$ the impinging droplets run off and do not freeze. The two icing conditions on figure $10(a)$ were done at the same OVM and the same upstream droplet mass (LWC $V \cdot T=$ constant), with the 0012 afrfoll at a $4^{\circ}$ angle of attack.

The variation of the section drag coefficlent with temperature for each lcing condition is plotted on figure $10(b)$. The drag coefficlent variation with total temperature is similar for each condition. The peak drag coefficlent occurs at about $-5{ }^{\circ} \mathrm{C}$, which corresponds to where the horns are the largest. Below about $-15^{\circ} \mathrm{C}$ the drag coefficlent does not change much, because the ice shape does not change much. 


\section{Ice structure}

The structure of the ice is verv dependent upon the temperature at which it forms. A good way to look at the ice structure is to cut off thin ice samples (about $0.3 \mathrm{~cm}$ thick) from the ice accreted on the airfoll and then photograph them with backlighting. The samples shown on figure 11 were obtained during the experiment at $209 \mathrm{~km} / \mathrm{hr}$ : the results of which are shown on figure 10. Rime ice is opaque and therefore appears to be black when backighted in figure 11, rather than white as it appears under icimal lighting.

Some untque features of the ice structure are apparent in the backitighted photos in figure 11. For example, ihore are very large bubbles in the ire formed at high temperatures $\left(-2\right.$ and $\left.-8^{\circ} \mathrm{C}\right)$. There are curlous streaks in the ice accreated at -15 and $-18{ }^{\circ} \mathrm{C}$. Upon close inspection of the actual ice these streaks are thin filaments that are either voids or perhaps rime ice. At the upper and lower edges of the four coldest ice shapes, closely packed rime ice feathers (look black when backlighted) have formed. The individual spread-out rime feathers that are downstream. on the lower surface are lost during the tce sampling process.

Additional information about the ice structure can be obtalned by looking at very thin ice samples under polarized light. Individual ice crystals can be seen because each crystal will polarize the light differently and produce a different color. Figure 12 shows the polarized light results in black and white for glaze and rime ice samples. The conditions for these samples are essentially the same as two cases on figure 11: the streaked glaze ice at $-15{ }^{\circ} \mathrm{C}$ and the rime ice at $-26{ }^{\circ} \mathrm{C}$. These photos show that the ice crystals for the streaked glaze condition are very large, whereas the rime ice crystals are very small. The large crystals are normally formed by a gradual freezing proce', whereas the small crystais for rime lce suggests the freezing process was rapld. Do not be confused by the superimposed grid lines showing through the rime ice sample.

\section{Effect of Alrspeed}

Alrspeed can have a large effect on the ice shape and the resulting section drag coefficient, as evidenced by the results on figure 13 . Only the velocity was varied in this comparison. This data set and the data set at $209 \mathrm{~km} / \mathrm{hr}$ on flgure 10 (b) form part of a three dimensional plot showing the combined effects of alrspeed and temperature. The very large horns accreted at the highest alrspeed were so large they caused the flow to separate over the entire suction side of the alrfoll.

\section{Effect of Drop Size}

The effect of droplet stze is shown on figures 14(a) and (b) for a number of cases (A to $F)$. The icing conditions for each case are different; they are listed in the table on figure 14(a). Each case involves a large variation in the drop stze (DVM) with each other parameter held constant. Figure 14(0) shows the effect of drop stze on the ire shape, while figure 14(a) shows the effect upon the resulting drag coefficient. Cases $A$ and $E$ are glaze ice cases that exhiblt a very large drop size effect upon the ice shape and resulting drag. In particular, the drop size has a very large effect on the angular location of the upper surface horn. The effect on the other glaze ice shapes 
( $B$ and $D$ ) is much less. Rime ice case $C$ shows little change in the shape; only the effect of the larger catch efficienry with bigger drops is shown. case $F$ the ice changed from rime to more like glaze. Cases $A, B, C$, and $F$ share the same icing conditions with the $209 \mathrm{~km} / \mathrm{hr}$ data set on figure 10 . By using these two data sets, one could plot a three dimensional plot showing the combined effects of drop size and total temperature. It shows that the drop size effect is greatest wherever the temperature effect is greatest.

\section{Effect of LWC}

Figure 15 shows the effect of liquid water content (LWC) on the lce shape and the resulting drag coefficlent for two Icing conditions where only LWC was varied. Except for the highest $\mathrm{LWC}$ for the $-18^{\circ} \mathrm{C}$ case, the ice shape changed very little in shape. These two data sets also form a three dimensional plot with figure 10 which shows the combined effects of LWC and total temperature. Once again, the LWC effect is greatest wherever the temperature effect is greatest.

\section{Roughness of the Ice Surface}

The roughness of the surface of the ice was sampled for a few of the cases previously described. A small strip of ordinary modeling clay was pressed on to the ice to make a mold of the ice surface. The clay impression was then photcgraphed.

The effect of temperature on the roughness in the stagnation region is shown by a series of photographs on figure 16(a). The roughness of the ice surface is obviously a strong function of temperature. The size of the roughness elements, (1.e. we helght of the $h 111 \mathrm{~s}$ ) varies from about $0.2 \mathrm{~cm}$ at $-8{ }^{\circ}$, down to less than $0.01 \mathrm{~cm}$ at the lowest temperatures.

The effect of time on the lce roughness is shown by the photographs on figure 16(b). These photos sliow that for the glaze ice conditions the roughnes increases with time, rapldly at first then at much slower later. Rime tce, not shown here, never gets rough compared to glaze.

Although no other clay molding was done, a close look at the photographs of the ice accretion for each run reveals additional information about roughness changes for glaze ice. Increased drop size increases the size of the roughness up to a point, then the roughness decreased with increased drop size. Alrspeed seems to have a small effect; but that would not be true when kinetic heating becomes important at higher alrspeeds.

\section{Effect of Ice Shape and Roughness on Droplet Catis}

01d ice accretion theory ignores the effect of ice shape on the local droplet catch.

To test this thesis, a simple and direct technique was used to determine how the ice shape and its roughness affects the local droplet catch. It used the fact that droplets freeze on impact under rime icing conditions. A 3 min rime spray was accreted on top of an initlal ice shape. The alrspeed and DVM 
are the same as for the initial ice, because these variables affect the catch. After the $3 \mathrm{~min}$ spray, a thin sample of the two-layer ice was removed from the alrfo11, backlighted, and photographed. Two initial ice shapes were used: one was a $15 \mathrm{~min}$ glaze ice shape and the other was a $15 \mathrm{~min}$ rime ice shape. Figure 18 gives a measure of the local droplet catch on the initial glaze and rime lice shapes by simply measuring the local variation of the thickness of 3 min rime spray on top. The initial rime ice was sprayed with water soluble dye to differentiate the initial rime ice from the additional rime ice.

A few things stand out from these photos. The additional rime spray only accreted on the upstream surfaces of the initial rime and glaze ice shapes. The accretion for the rime shape is greatest on the splke. Tive maximum accretion for the glaze shape occurred on the horns and also on top of the local roughness hills. There was no accretion in the cavity for the glaze ice on flgure 18; which could explain the large volds in the ice. There is no accretion on the sides, only on the upstream surfaces. These resuits suggest that the local catch effect of the ice shape and roughness can explain th differences between rime and glaze ice shapes when only the temperature is changed.

\section{Effect of Partial Ice Removal}

Gray (ref. 1) suggested that the lce on the upper surface near the leading edge makes the predominant contribution to the drag of an alrfoll. That would mean that an lce accretion theory or a delcing system could concentrate on treating the upper surface 1ce. Let us put this thesis to the test at an icing condition favoring the thesis; namely a glaze ice shape with large horns. The ice shape used in this test is shown on figure 19; the 1ce was accreted at $4^{\circ}$ then the drag was measured at several angles of attack (1.e., a drag-angle sweep). Ice was then removed below cut $A$ and another drag-angle sweep was made. A similar drag-angle sweep was made after lce above cut $B$ was removed from a repeated ice accretion. These three drag-angle sweeps were plotted on figure ly. Clearly the bottom horn of ice (pressure side) is generally less li.pportant than the suction side horn; but it cannot be neglected even for this case, which favored Gray's thesis.

\section{Comparison with old Correlation}

Gray (ref. 1) correlated the change in the section drag coefficlent to the lcing time, airsfeed, LWC, total and maximum catch efflclencles, total temperature, and the alrfoll geometry. The alrfoll geometry includes the chird length, leading edge radius/chord, the angle of attack and the angle of attack at which ice was accreted. The change in section drag coefficient, $\Delta C_{D}$. is the drag coefficlent for the iced airfoll minus thr ilean airfoll drag coefficient.

Gray's correlation was formulated from limited data for six types of alrfolls over a wide range of icing conditions. The predictions from Gray's correlation for the 0012 alrfoll test conditions are compared to the measured values of $\Delta C_{D}$ on figure 20 . The line of perfact agreement gives a reference to determine how well the predicted value's of $\Delta C_{D}$ agree with the measured values of $\Delta C_{D}$. Only a few points fall near the line of perfect agreement. Gray's correlation overpredicts the change in drag by a substantial amount. The same poor agreement was noted in reference 4 with a large 
G/A wing in the IRT. We carrot offer an explanation for chis bad agreement at this time.

\section{CONCLUDING REMARKS}

1. Extensive data for ice shapes and the resulting drag were obtained for a NACA 0012 airfoll over a wide range of icing conditions. These data will be useful in evaluating and formulating ice accretion analyses and also performance penalty predictions.

2. The old correlation by Gray for the drag increase caused by ice agreed poorly with the measured results. This same poor agreement has been noted by other recent investigators.

3. Additional results were obtained wilch will prove helpful in understanding and predicting the ice accretion: ice structure, roughness, effect of ice shape on droplet catch, and what parts of the ice shape are important. 


\section{APPENOIX A}

NOHE NCLATURE

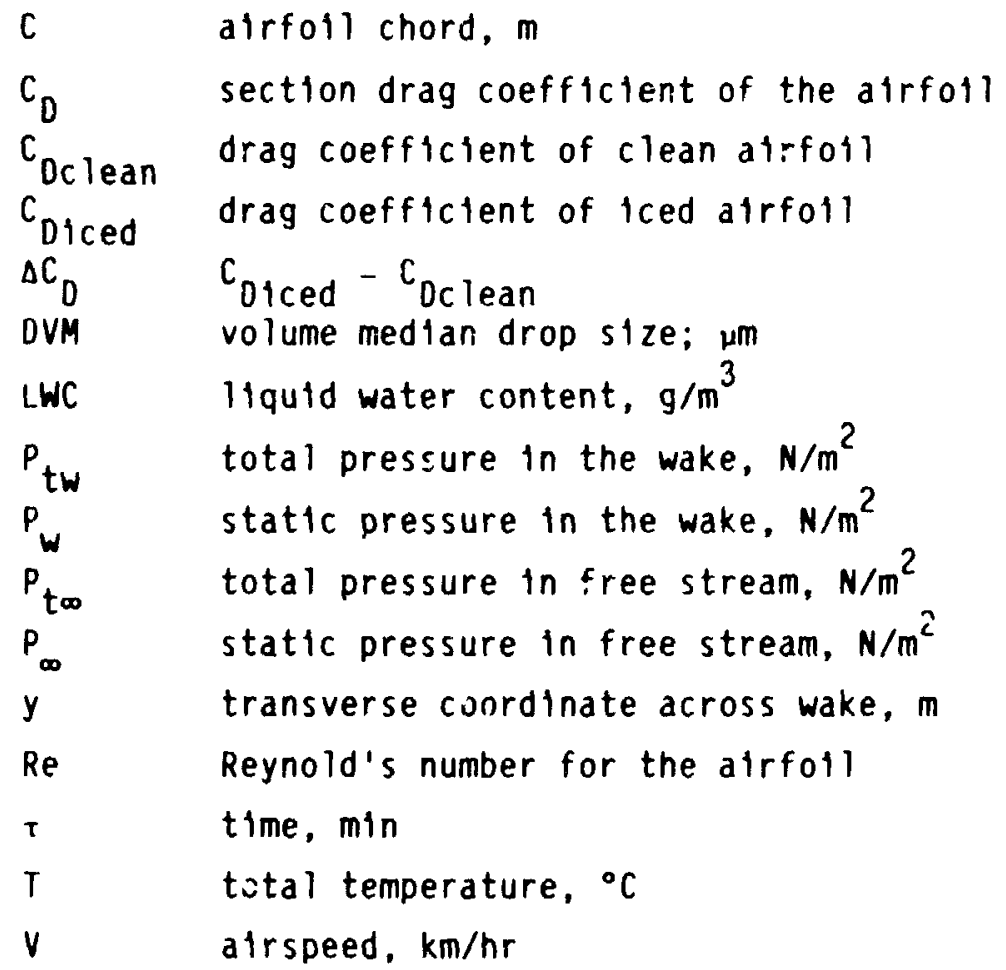


This appendix discusses the wake survey method used to measure the drag coefficlent, how it was calculated, the transducers used, and some possible error sourccs.

Description of wake survey. - The section drag of the 20 wing model in the center-span plane (see traverse path on $\mathrm{fig}$. I(b)) was measured using a conventional traversing wake survey probe. The probe is two airfoll chords downstream of the alrfoll trafling edge as shown in figure l(a).

When activated, the wake survey probe automatically traversed the wake of the alrfoll. The iraverse speed of the probe was adjusted so hat no lags in the probe response existed. Orag surveys were only taken when the TRT cloud was turned off and the air was free of any cloud. While the spray was on the probe was positioned behind an anti-iced protective shield to prevent ice from being accreted on its tip. The nrobe was not heated in order to keep the probe tip as small as possible. The probe support was anti-iced.

Calculation of the section drag coefficient. - As the probe trayersed the wake, the instantancous analog signals from the four pressure transducers as well as a sigrial from a position potentiometer were digitized by an $A / D$ converter. The digital information was passed on to the NASA Lewts central data recording/computing facllity where that data was convertes to engineering units. The wing section drag coefficient was calculated using the Jones equation (ref. 5):

$C_{D}=\frac{2}{C} \int \sqrt{\frac{P_{t w}-P_{W}}{P_{t \infty}-P_{\infty}}}\left|1-\sqrt{\frac{P_{t w}-P_{W}+\left(P_{W}-P_{\infty}\right)}{P_{t \infty}-P_{\infty}}}\right| d Y$

In order to deterinine the approprlate end points to be used in the drag coefficlent integral, an on-line plot was displayed during the test program for each data reading which showed the difference in total pressure ( $P_{t_{\infty}}-$ $\left.P_{t w}\right)$ as a function of probe position. From this plot, the viscous wake end points could be identifled and the drag coefficlent could then be calculated.

The efferts of the blockage caused by the wake survey traverse were accounted for in this calculation. Tunnel velocity measurements with ard without the alrfoll in place indicated that the blockage caused by the traverse increased the local incldent a!rspeed by approximately 4 percent. The tunnel blockage caused by this very sm.ll alrfoll can be neglected.

Iiansoucers. - A 15 pSI absolute transducer was used to measure the local total pressure level sensed by the probe. A 1 psi differentlal pressure transducer was used to measure the total-minus-statlc pressure level sensed by the pltot-static probe tip. A simllar pressure transducer was used to measure the IRT alrspeed well upstream of the alrfoll. All four transducers are located outside of ine test :action to shleld them from the extreme temperature environment insioe of the test section. 
Effect of rloud nonuniformits on drag measurements. - The LWC of the icing cloud in the IRT is not unlform across the entire span of the airfoil $(1.8 \mathrm{~m})$. The untform region is over the middle .6 meters of the tunnel; the LWC then drops to near zero at the tunnel walls. Therefore the ice shape in the middle third of the span will be uniform, but the upper and lower thirds of the span w1ll have less 1ce. W1ll this nonunlform ice accretloll affect the drag coefficient measuren at the center span of the alrfoll The eastest way to check io see if it does is to gradually remeve the lce from the top and bottom of the airfoll span and observe how the measured drag changes. Figure 23 contains the drag results of two expertments where the ice span was gradually reduced from the full tunnel span down to only the middle 0.3 meteis. For the glaze and rime ice shapes this major reduction in the span of ice had only a small effect on the measuied drag. Clezrly a large unlform cloud is not necessary for adequate section drag measurements in the center of the span. This conclusion should also be true for less severe ice shapes and for lower angles of attack.

Effect of frost. - One of the pioblems with testing in an icing facllity with its turbulent saturated airstream, is that a very thin frost layer will collect on the aft parts of the airfoll. Frost does not normally occur in flight. The IRT turbulence intensity is low (about one-haif percent) but flight turbulence would be an order of magnitude lower. The higher turbulence is belleved to be the cause of the unnatural frost bulld up in the IRT on the aft surfaces. Does this aft frost have to be removed before ccurate drag measurements can be made

A simple experimental comparison is made on figure 22 using the same glaze arid rime icing conditions that were used in figure 21 . The drag is measured as sprayed whthout removing the thin frost layer over the aft surfaces of the alrfoll. Then the aft frost layer is scraped of $f$ down to the bare alrfoll surface. Figure 22 shows that the thin frost layer can have d large effect on the measured drag coefficlent when the drag rise of the ice is smal1, such as with rime ice. The $t$ ffect of the frost is not so great with glaze ice. To be on the safe side all aerodynamic measurements were made with the frcst removed.

The rime feathers on the lowe. surface (see the photographs on $f 1 g .9$ ) were then removed to see what affect they would have at one angle. Figure? shows that their affect is sinall compared to the effect of the ice shape and the frost. Rime feathers are also seen in flight tests into natural icing. 


\section{h. PIENCES}

1. Gray, V.ll., "ficuiction of Aerodynamic Penaities caused by Ice Formations on Varlous Airfolls," NASA TN D-2166, 1964.

2. 0lsen, W., Takeuchi, D., and Adams, K., "Experimental Comparison of Icing Cloud Instruments," AIAA Paper 83-0026, 1983.

3. Abbott, I.H., and Von Doenhoff, A.E., Theory of Wing Sections Including a Summary of Airfofl Data. Dover. New York., 1958.

4. Shaw, R.J., Sotos, R.G., and Salano, .R., "An Experimental Study of Atrfoll Icing Characteristics," AIAA 82-0283, 1982.

5. Gregorek, G., Hoffmann, M.J., We1sloge 1, G.S., and Vogel, G.M., "In-f11ght Measurements of the GAW-2 Aerodynamic characters.,tics," SAE Paper 770461: Mar. 1977. 


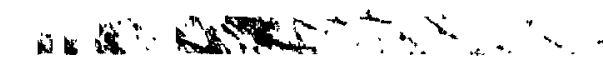

\section{ortar.". : $;.$ \\ or Gor: GuLATE}

\begin{tabular}{|c|c|c|c|c|c|c|c|c|c|}
\hline \multirow{2}{*}{$\begin{array}{l}\text { Run } \\
\text { num } \\
\text { Der }\end{array}$} & \multicolumn{2}{|c|}{ Tunnel condit ions } & \multicolumn{3}{|c|}{ Soray conditions } & \multicolumn{2}{|c|}{$\begin{array}{c}\text { Angle of attuck. } \\
\text { deg }\end{array}$} & \multirow{2}{*}{$\begin{array}{c}\text { Orag } \\
\text { coefficient, } \\
6 \\
0\end{array}$} & \multirow[t]{2}{*}{ Cominert } \\
\hline & $\begin{array}{c}\text { Airspeed. } \\
\mathrm{k} m \mathrm{~m} / \mathrm{hr}\end{array}$ & $\begin{array}{l}\text { Total } \\
\text { temperature. } \\
\text { c }\end{array}$ & LWC: & om. & $\begin{array}{c}\text { Thene. } \\
\min \end{array}$ & Spray & Aero & & \\
\hline \multicolumn{10}{|c|}{ Varying time and angle } \\
\hline $\begin{array}{l}S H-1 \\
S H-2 \\
S H-3 \\
S H-4 \\
5 H-5 \\
S H-6 \\
S H-7 \\
S H-8 \\
5 H-9 \\
S H-10 \\
S H-11 \\
S H-12 \\
S H-13 \\
S H-14 \\
S H-15 \\
S H-16 \\
S H-17\end{array}$ & 209 & -26 & 1.02 & 20 & $\begin{array}{r}5 \\
15 \\
2 \\
15 \\
5 \\
2 \\
15 \\
5 \\
2 \\
15 \\
2 \\
15 \\
5 \\
2 \\
15 \\
5 \\
2 \\
\end{array}$ & $\begin{array}{l}0 \\
0 \\
0 \\
4 \\
4 \\
4 \\
8 \\
\\
\\
4 \\
4 \\
4 \\
0 \\
0 \\
\end{array}$ & $\begin{array}{l}0 \\
0 \\
0 \\
4 \\
4 \\
4 \\
8 \\
\\
\\
4 \\
4 \\
4 \\
0 \\
0 \\
0 \\
\end{array}$ & $\begin{array}{l}\text { Orag not } \\
\text { reported } \\
\text { berause } \\
\text { frost was } \\
\text { not removed } \\
\text { in these } \\
\text { early rens }\end{array}$ & \\
\hline \multicolumn{10}{|c|}{ Drag angle smep with one ice shape } \\
\hline $\begin{array}{l}0-10 \\
0-11 \\
0-12 \\
0-13 \\
0-14 \\
0-15 \\
0-26 \\
0-27 \\
0-28 \\
0-29 \\
0-30 \\
\end{array}$ & 209 & -26 & 2.1 & 20 & 3 & 4 & $\begin{array}{c}4 \\
8 \\
2 \\
0 \\
-3 \\
5.5^{\circ} \\
4 \\
8 \\
11 \\
-3 \\
0 \\
\end{array}$ & \begin{tabular}{|}
0.02767 \\
.07647 \\
.02421 \\
.02199 \\
.02683 \\
.0358 \\
0.01077 \\
.01610 \\
.03148 \\
.01268 \\
.01172
\end{tabular} & $\begin{array}{l}\text { Bad flow separg- } \\
\text { ration a } \$ 5.5^{-} \\
\text {Bad flow separa- } \\
\text { tion a, } 12.5^{2}\end{array}$ \\
\hline \multicolumn{10}{|c|}{ Ice shape and drag variation with angle } \\
\hline $\begin{array}{l}0-4 \\
0-8 \\
0-9 \\
0-26 \\
0-31 \\
0-32\end{array}$ & $\begin{array}{l}209 \\
209\end{array}$ & $\begin{array}{l}-8 \\
-26\end{array}$ & $\begin{array}{l}2.1 \\
1.0\end{array}$ & $\begin{array}{l}20 \\
12\end{array}$ & 5 & $\begin{array}{l}1 \\
0 \\
8 \\
4 \\
0 \\
8\end{array}$ & $\begin{array}{l}4 \\
0 \\
8 \\
4 \\
0 \\
8\end{array}$ & $\begin{array}{l}0.03382 \\
.02294 \\
.05260 \\
.01017 \\
.00855 \\
.00947 \\
.01280\end{array}$ & $\begin{array}{l}\text { Some flow } \\
\text { separation } \\
\text { for run } 0-9\end{array}$ \\
\hline \multicolumn{10}{|c|}{ Effect of temperature } \\
\hline $\begin{array}{l}S-29 \\
S-30 \\
5-31 \\
5-32 \\
S-41, \\
S-70 \\
S-45 \\
S-69 \\
5-36 \\
S-72\end{array}$ & $20:$ & $\begin{array}{l}-2 \\
-1 \\
-5 \\
-8 \\
-18 \\
-26 \\
-15 \\
-12 \\
-20\end{array}$ & 1.3 & 20 & 8 & 4 & 4 & \begin{tabular}{|l|}
0.02807 \\
.02647 \\
.06036 \\
.02949 \\
.021 \\
.02161 \\
.0210 \\
.0194 \\
.01105 \\
.02072 \\
.01773
\end{tabular} & \\
\hline $\begin{array}{l}s-113 \\
s-116 \\
s-115 \\
s-116 \\
s-115 \\
\end{array}$ & 338 & $\begin{array}{l}-2 \\
-8 \\
-12 \\
-17 \\
-26 \\
\end{array}$ & 1.05 & 20 & 6.2 & 4 & 4 & $\begin{array}{l}0.0756 \\
.0606 \\
.0370 \\
.0284 \\
.0238 \\
\end{array}$ & \\
\hline \multicolumn{10}{|c|}{ Effect of velocity } \\
\hline $\begin{array}{l}5-33 \\
5-34 \\
5-35\end{array}$ & $\begin{array}{l}249 \\
209 \\
336\end{array}$ & -8 & 1.3 & $2 x$ & 8 & 4 & 4 & $\begin{array}{c}0.01622 \\
.0296 \\
.1182 \\
\end{array}$ & $\begin{array}{l}\text { Bad flow } \\
\text { separstion } \\
\text { for run } \$-35\end{array}$ \\
\hline \multicolumn{10}{|c|}{ Effect of drop size } \\
\hline $\begin{array}{l}5-22 \\
5-23 \\
5-24 \\
5-80 \\
5-23 \\
5-26 \\
5-21 \\
5-53 \\
5-51 \\
5-50 \\
5-50 \\
5-51 \\
5-52 \\
5-53 \\
5-57 \\
5-34 \\
5-58 \\
5-60 \\
5-61\end{array}$ & $\begin{array}{l}338 \\
209\end{array}$ & $\begin{array}{l}-8 \\
-26 \\
-8 \\
-26 \\
-2\end{array}$ & $\begin{array}{l}1.05 \\
1.3 \\
1.3 \\
1.3 \\
1.3\end{array}$ & $\begin{array}{l}26 \\
20 \\
14 \\
36 \\
26 \\
20 \\
14 \\
26 \\
20 \\
11 \\
20 \\
26 \\
14 \\
26 \\
20 \\
14 \\
26 \\
20 \\
14\end{array}$ & $\begin{array}{l}5.2 \\
8 \\
3 \\
8 \\
8\end{array}$ & $\begin{array}{l}4 \\
4 \\
4 \\
4\end{array}$ & $\begin{array}{l}1 \\
4 \\
4 \\
4 \\
4\end{array}$ & \begin{tabular}{|c}
0.01493 \\
.00364 \\
.01465 \\
.10055 \\
0.1266 \\
.0951 \\
.00309 \\
0.0196 \\
.01930 \\
.01206 \\
0.01941 \\
.0280 \\
.01154 \\
0.0196 \\
.01963 \\
.0121 \\
0.0344 \\
.02903 \\
.03147
\end{tabular} & \\
\hline \multicolumn{10}{|c|}{ Effect of LWC } \\
\hline $\begin{array}{l}3-54 \\
5-35 \\
5-36 \\
5-109 \\
5-110 \\
5-111\end{array}$ & & $\begin{array}{l}-0 \\
-10\end{array}$ & \begin{tabular}{l|}
1.0 \\
1.3 \\
1.6 \\
1.0 \\
1.3 \\
2.0
\end{tabular} & $\begin{array}{l}20 \\
20\end{array}$ & 8 & 4 & 4 & $\begin{array}{l}0.0262 \\
.0307 \\
.0456 \\
.0212 \\
.0246 \\
.0312\end{array}$ & \\
\hline
\end{tabular}


ORIGHVAL F:-

OF POOR Q Q

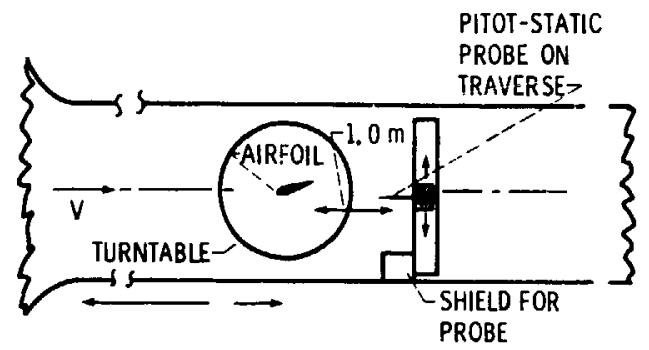

(a) Top view of test section.

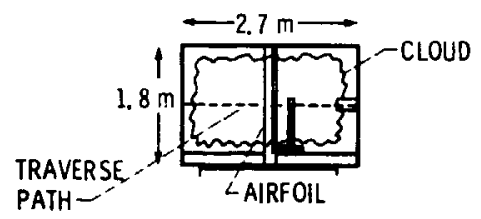

(b) Test section - looking downstream.

Figure 1. - Location of airfoil and wake survey traversing probe in the test section of the IRT.

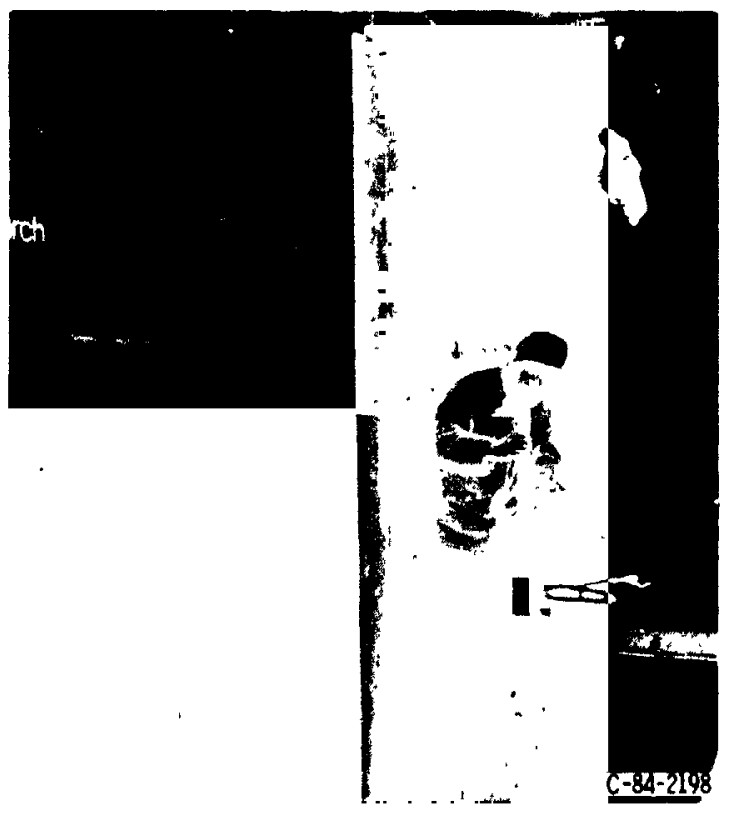

Figure 2 - The 0012 Airfoil and the Wake Survey Probe in the IRT. 


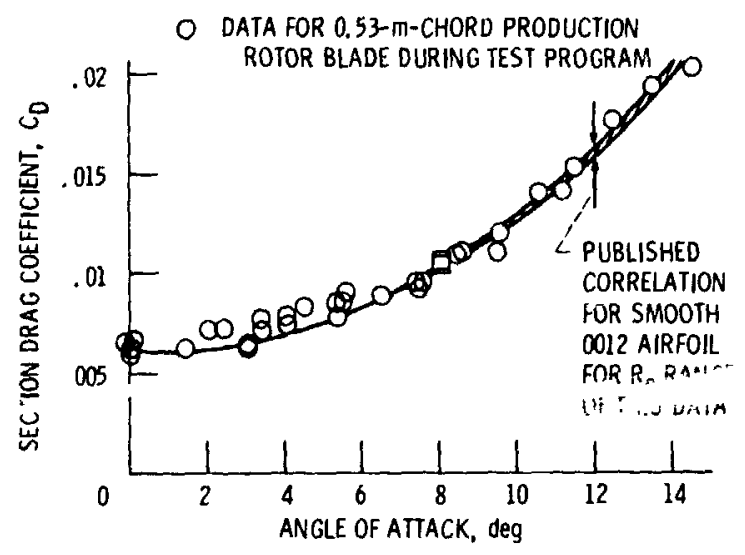

Figure 3. - Comparison of measured clean airfoil data with published data for the 0012 airfoil.

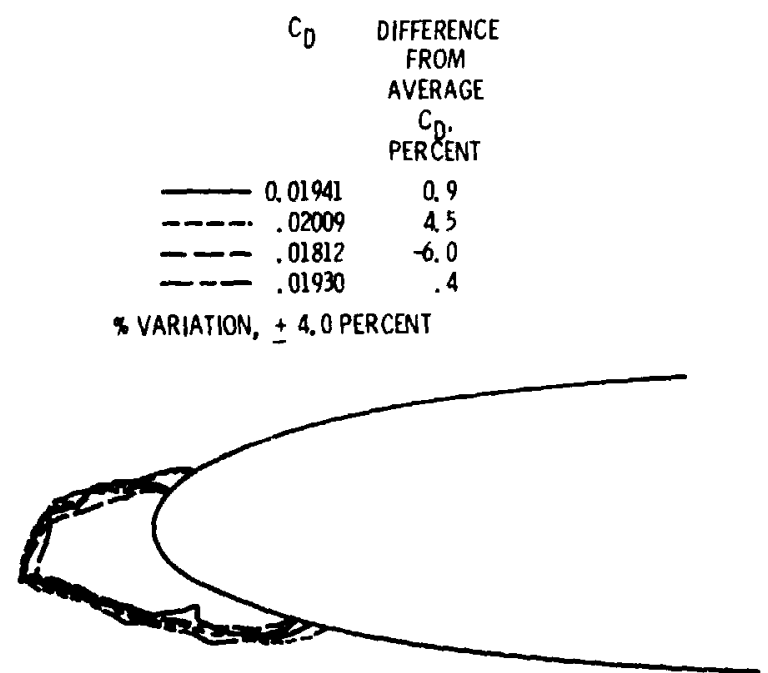

(a) DVM, 20 um; LWC, $1.3 \mathrm{~g} \mathrm{~m}^{3}$; time, $8 \mathrm{~min}$.

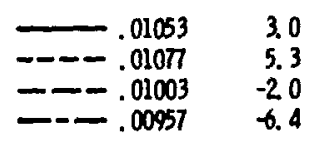

* VARIATION, \pm 5.0 PERCENT

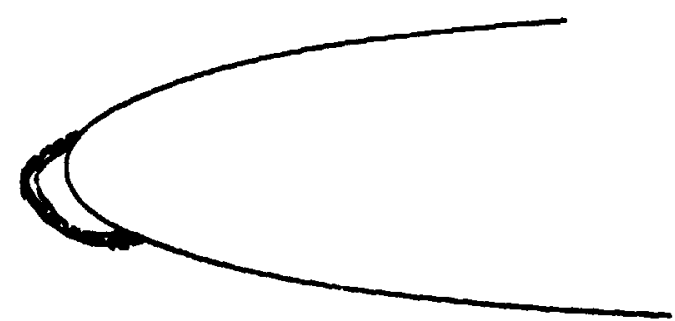

(b) DVM, $12 \mu \mathrm{m}$; LNC, $1.08 \mathrm{~g}^{3}$; time, $5 \mathrm{~min}$.

Figure 4 - Repeatability of ice shape and drag for rime ice shapes. Total temperature, $-26^{\circ} \mathrm{C}$; airspeed, $209 \mathrm{~km} / \mathrm{hr} ; 0.53-\mathrm{m}$-chord 0012 airfoil at $4^{\circ}$. 


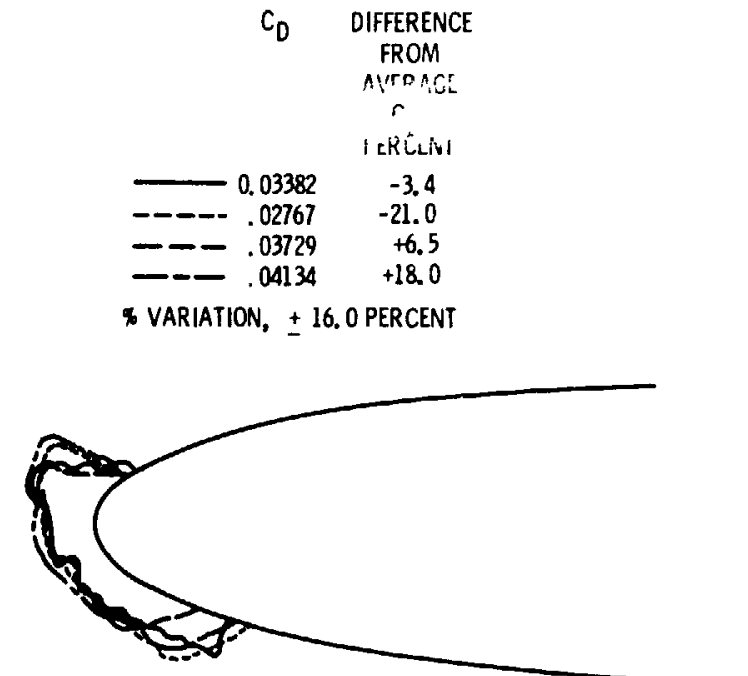

(a) DVM, $20 \mu \mathrm{m}$; LWC, $21 \mathrm{~g} / \mathrm{m}^{3}$; time, $5 \mathrm{~min}$.

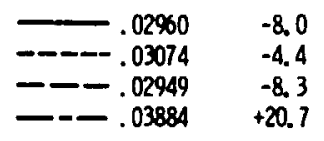

3. VARIATION, \pm 14.0 percent

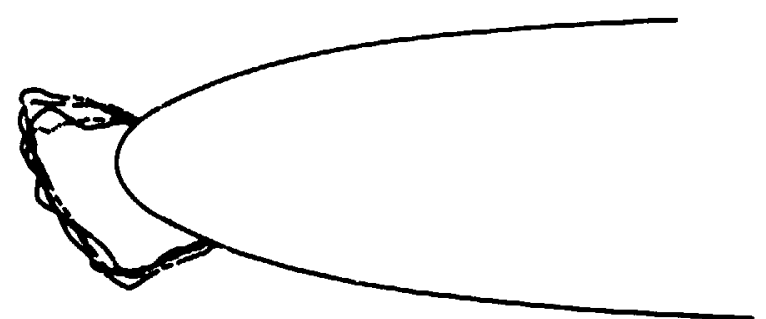

(b) DVM, $20 \mu \mathrm{m}$; LWC. $1.3 \mathrm{~g} / \mathrm{m}^{3}$; time, $8 \mathrm{~min}$.

Flgure 5. - Repeatability of ice shape and drag for glaze ice shapes. Total temperature, $-8^{\circ} \mathrm{C}$; airspeed, $209 \mathrm{~km} / \mathrm{hr} ; 0.53-\mathrm{m}$-chord 0012 airfoll at $4^{\circ}$ angle. 


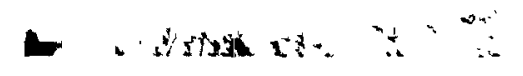

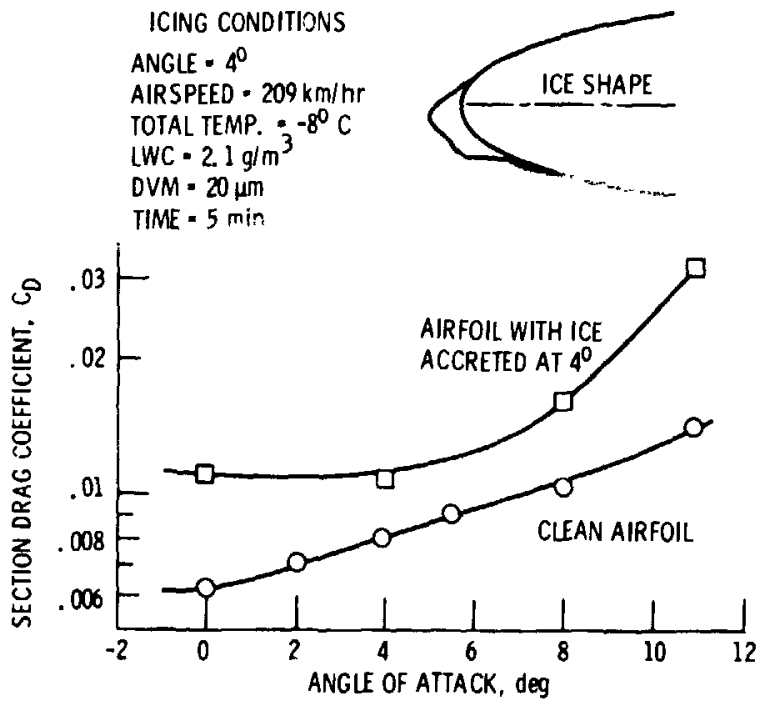

(a) Rime ice.

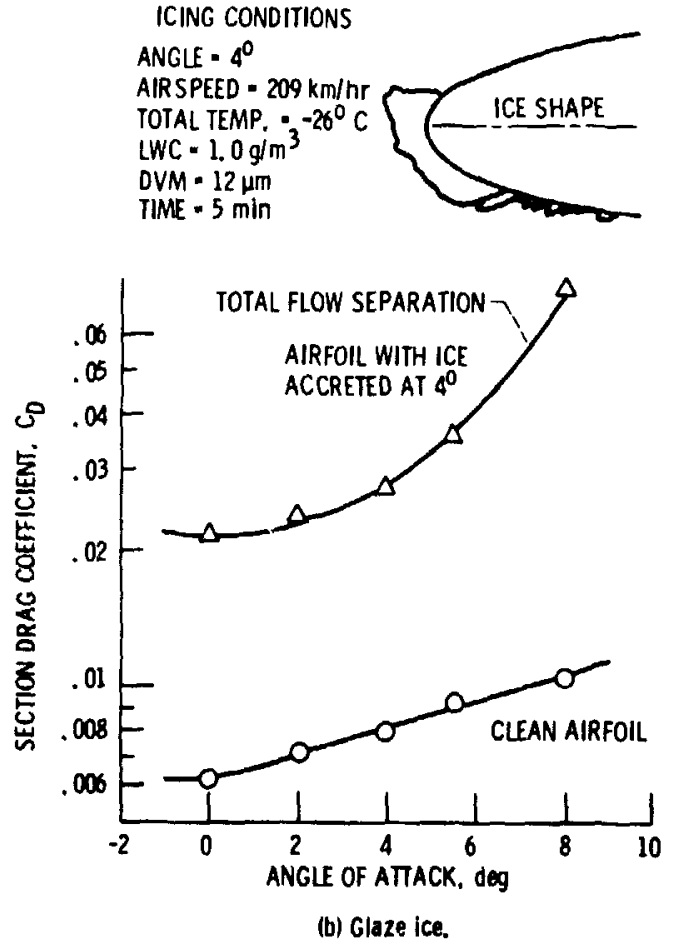

Figure 6. - Variation of the drag coelficient with angle of attack for ice accreted at a 40 angle of attack. 

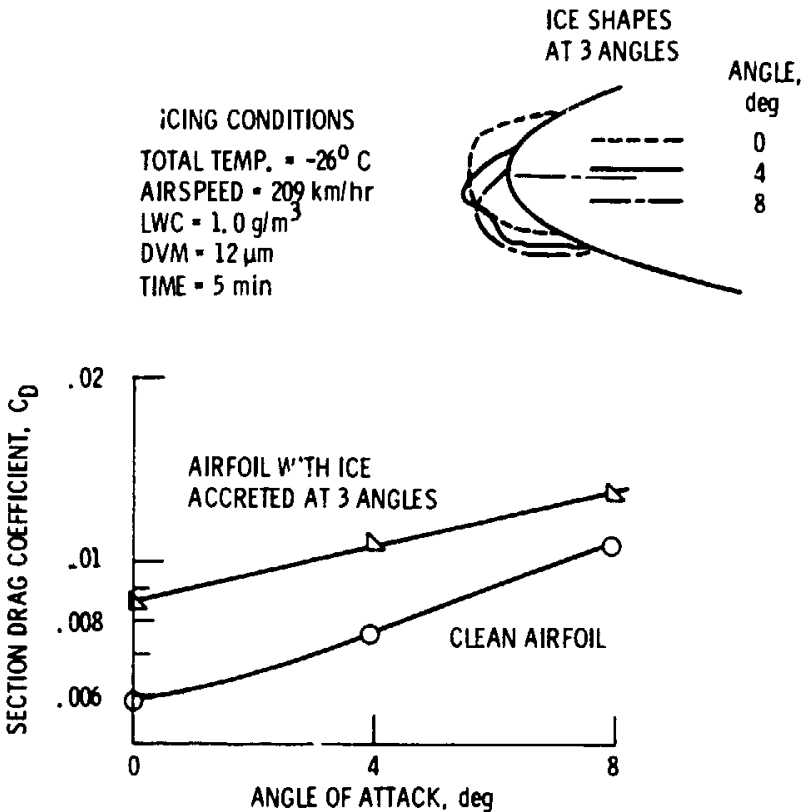

(a) Rime ice.

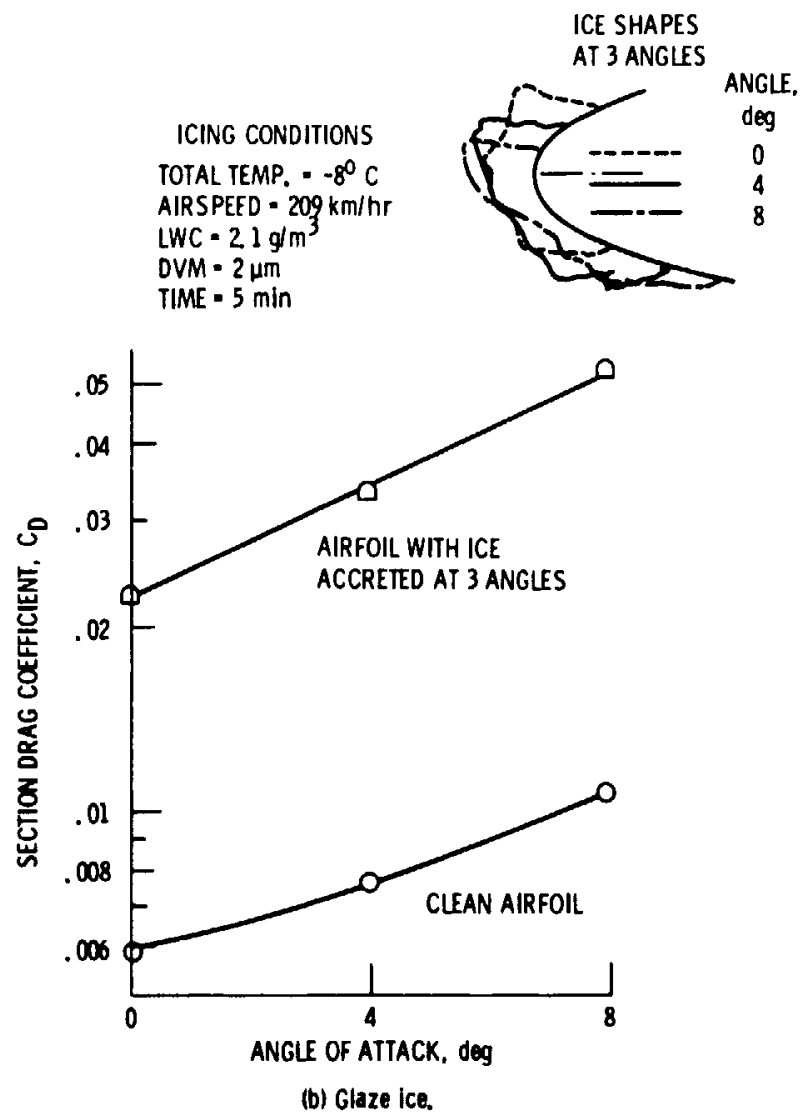

Figure 7. - Ice shape and drag for ice accreted at 3 angles. 
$+4+2+2$

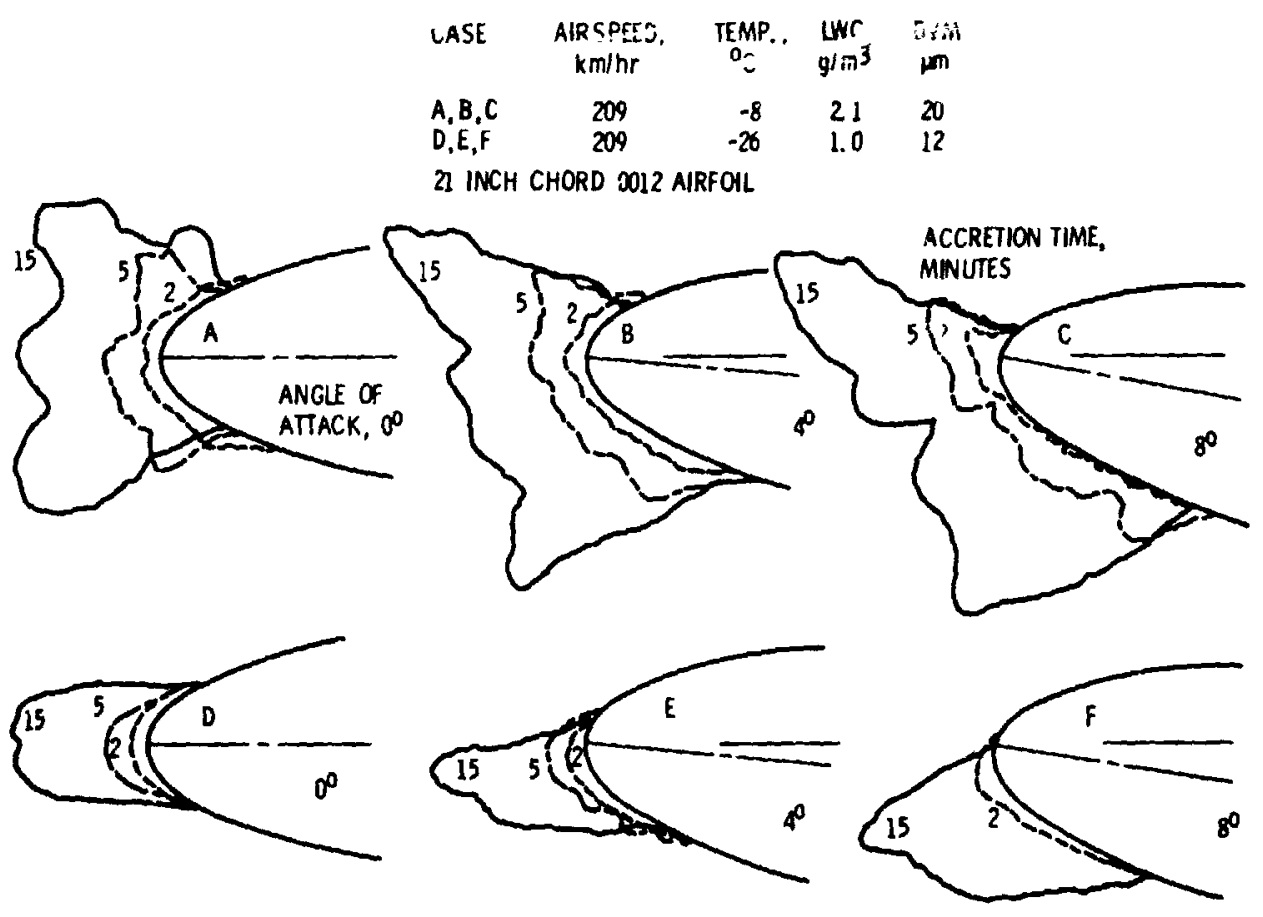

Figure 8. - Effect of time and the angle of attack on the ice shape alrfoll, NACA 0012 with a $0.53-m$-chord. 
4

OFitista: : I

OE POOA Qualitir

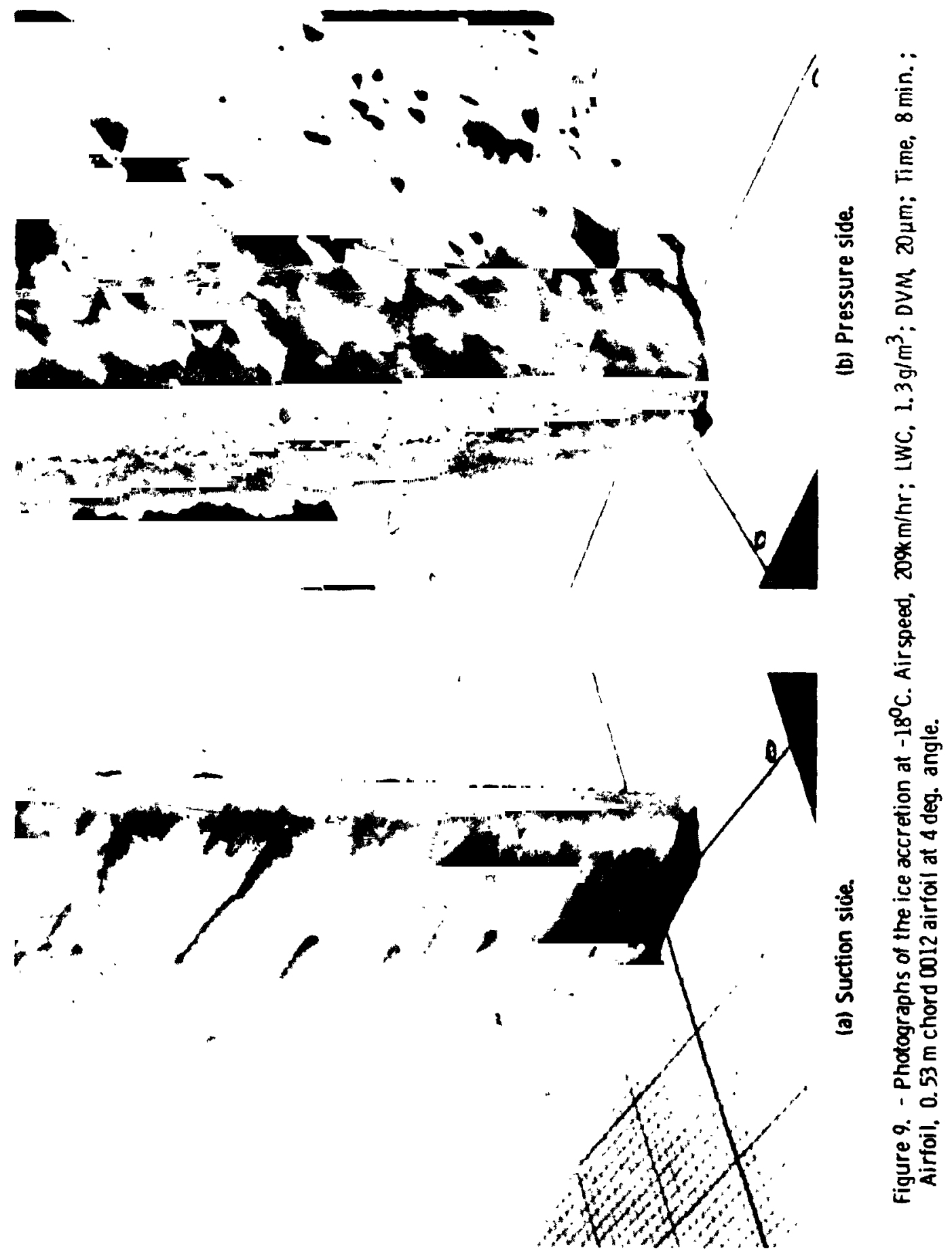


AIRSPEED, $209 \mathrm{~km} / \mathrm{hr}$; LWC, $1.3 \mathrm{~g} / \mathrm{m}^{3}$; TIME, $8 \mathrm{~min}$.

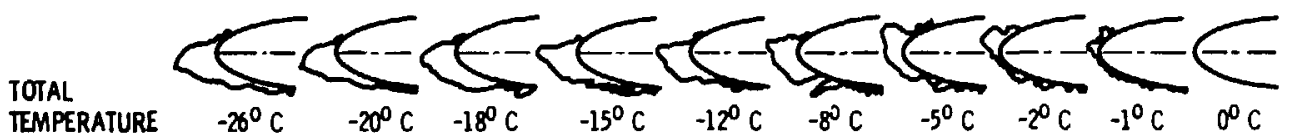

口 AIRSPEED, $338 \mathrm{~km} / \mathrm{hr}$ : LWC, $1.05 \mathrm{~g} / \mathrm{m}^{3}$; TIME, $6.2 \mathrm{~min}$.

TOTAL TEMPERATURE
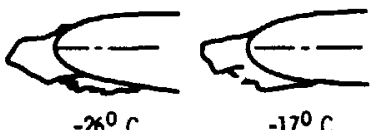

$-17^{\circ} \mathrm{C}$

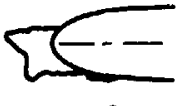

$-12^{\circ} \mathrm{C}$

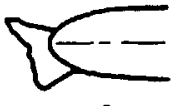

$-8^{\circ} \mathrm{C}$

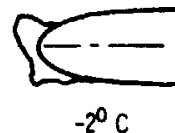

$-2^{\circ} \mathrm{C}$

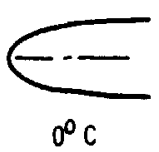

(a) lce shape.

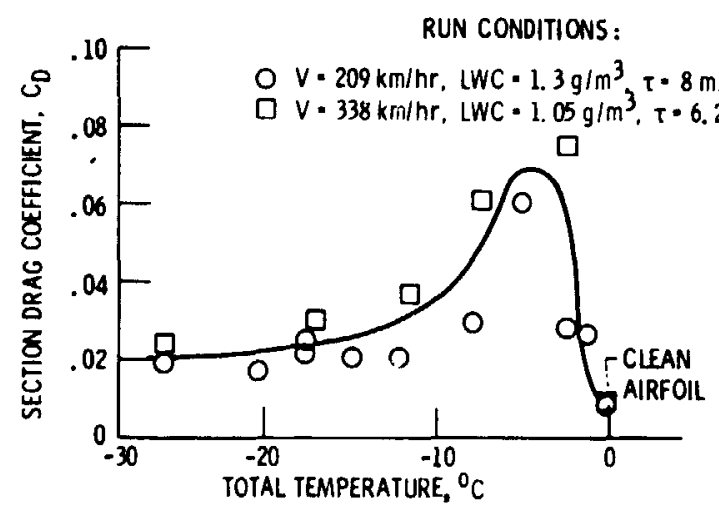

(b) Section drag coefficient.

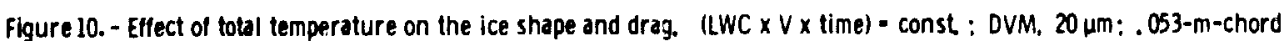
0012 dirfoil at $24^{\circ}$ angle of attack.
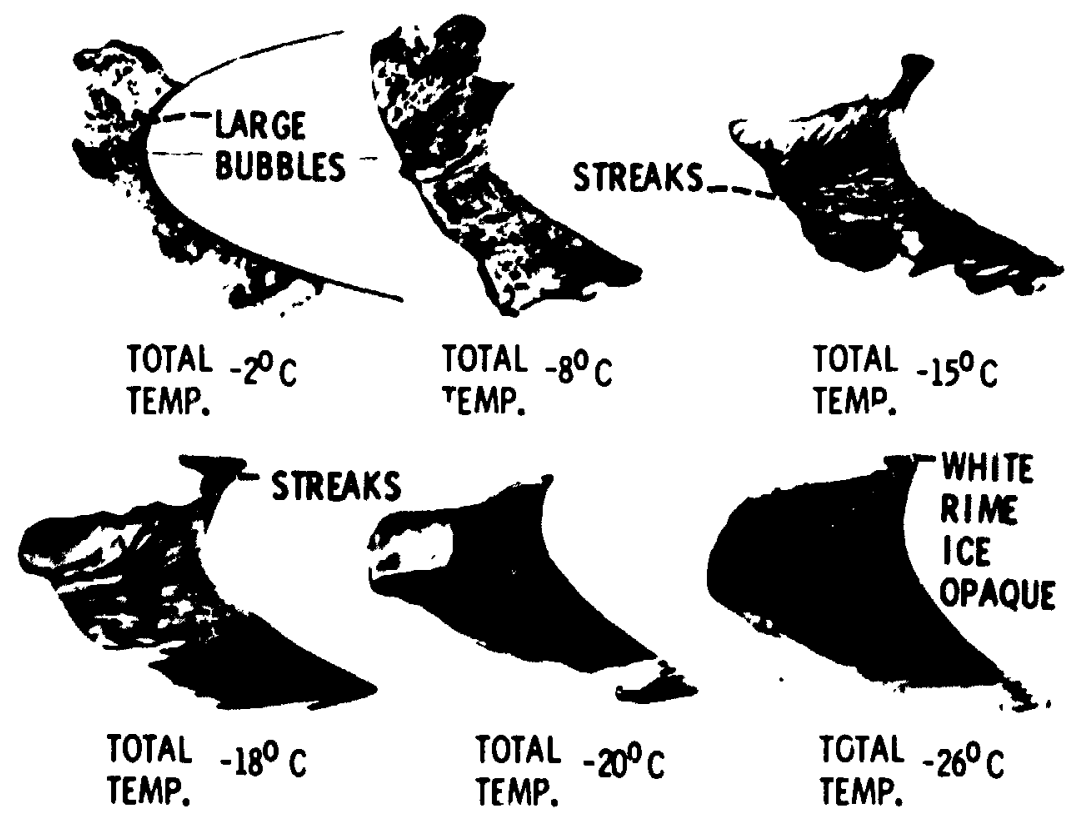

Figure 11. - Effect of temperature on the ice st ructure. Thin ice samples removed from the airfoil and backlighted; Airspeed, $209 \mathrm{~km} / \mathrm{hr}$; LWC, $1.3 \mathrm{~g} / \mathrm{m}^{3}$; DVM $20 \mathrm{~m}$; Time, $8 \mathrm{~min}$; Airfoil, $0.53 \mathrm{~m}$ chord 0012 airfoil at 4 deg. angle. 


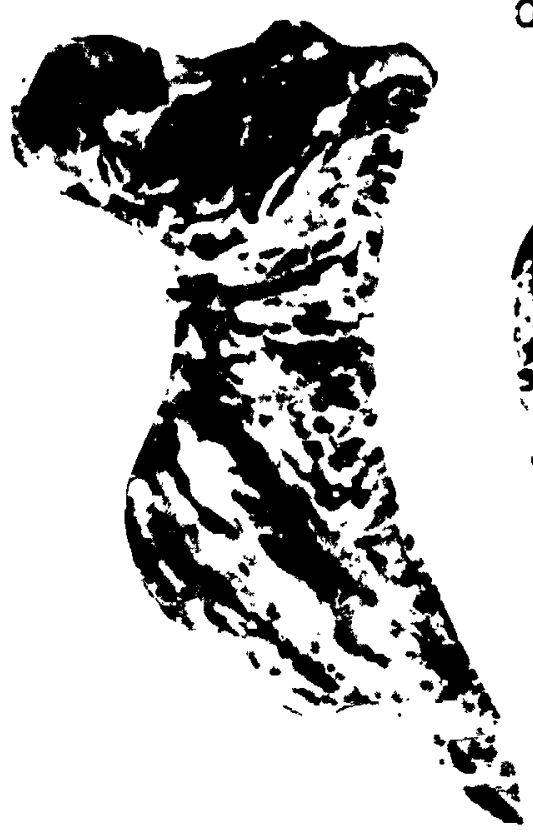

GLAZE ICE

(large crystals)
Clathings: :

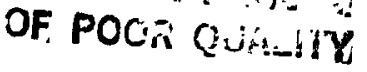

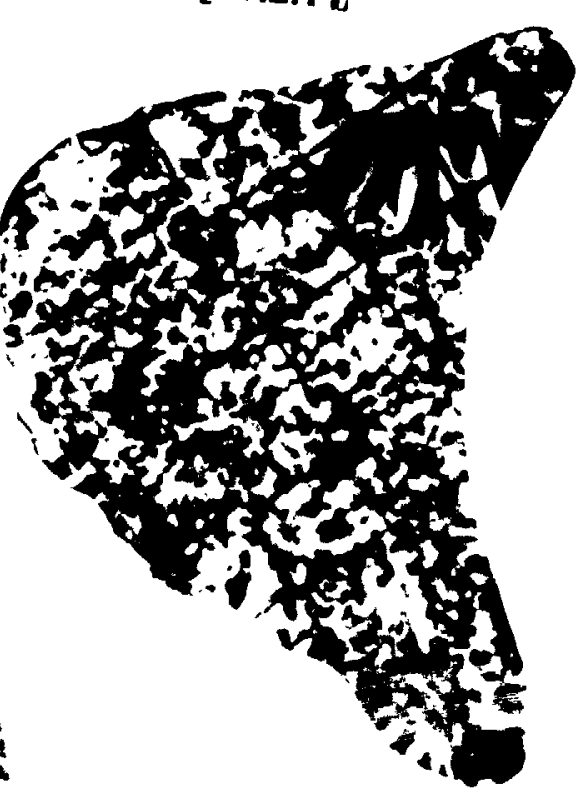

RIME ICE

(small crystals)

Figure 12 - Ice crystal size using polarized light.

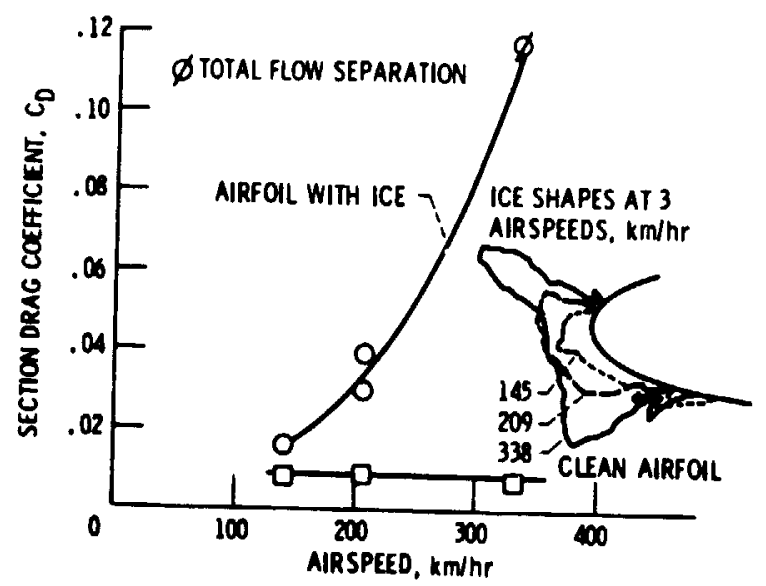

Figure 13. - Effect of velocity on the ice shape and section drag. Total temperature, $-8^{\circ} \mathrm{C}$ : IWC. $1.3 \mathrm{~g} / \mathrm{m}^{3}:$ OVM 20 un: time, $8 \mathrm{~min}$; airfoll. .53-m-chord 0012 airfoll it fo angle of atede. 


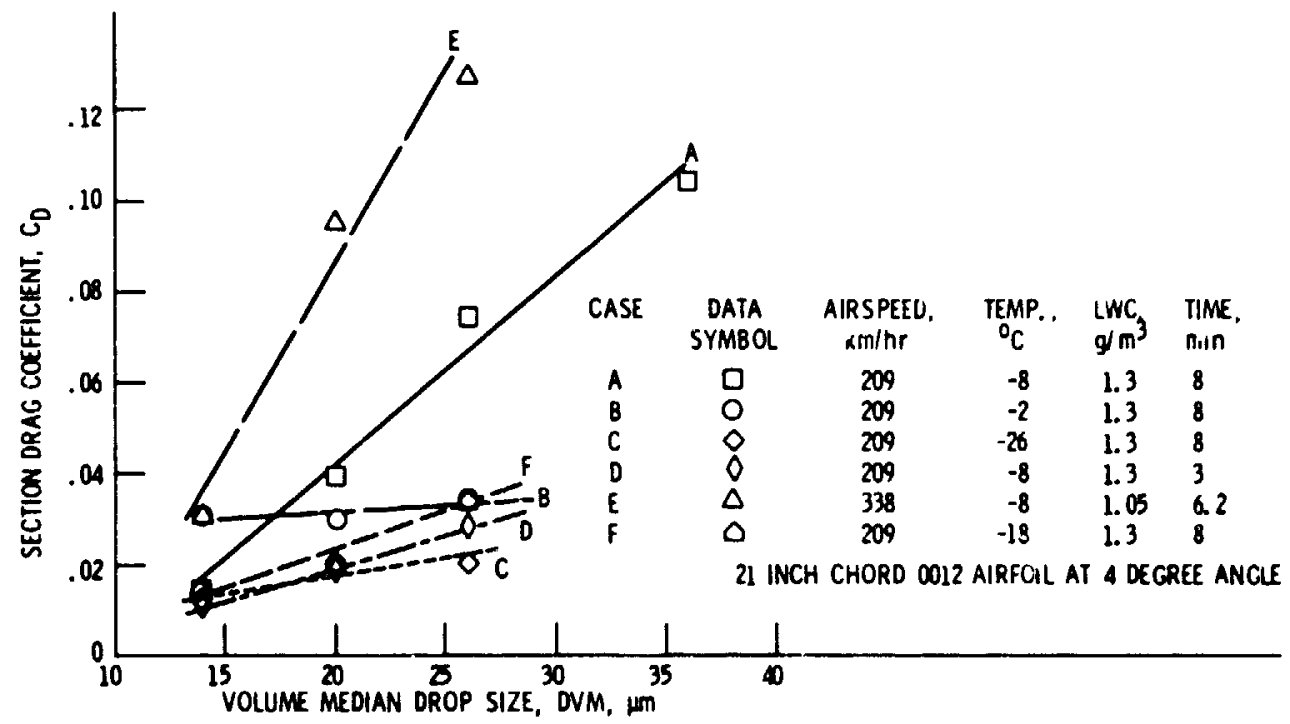

(a) Drag coefficient

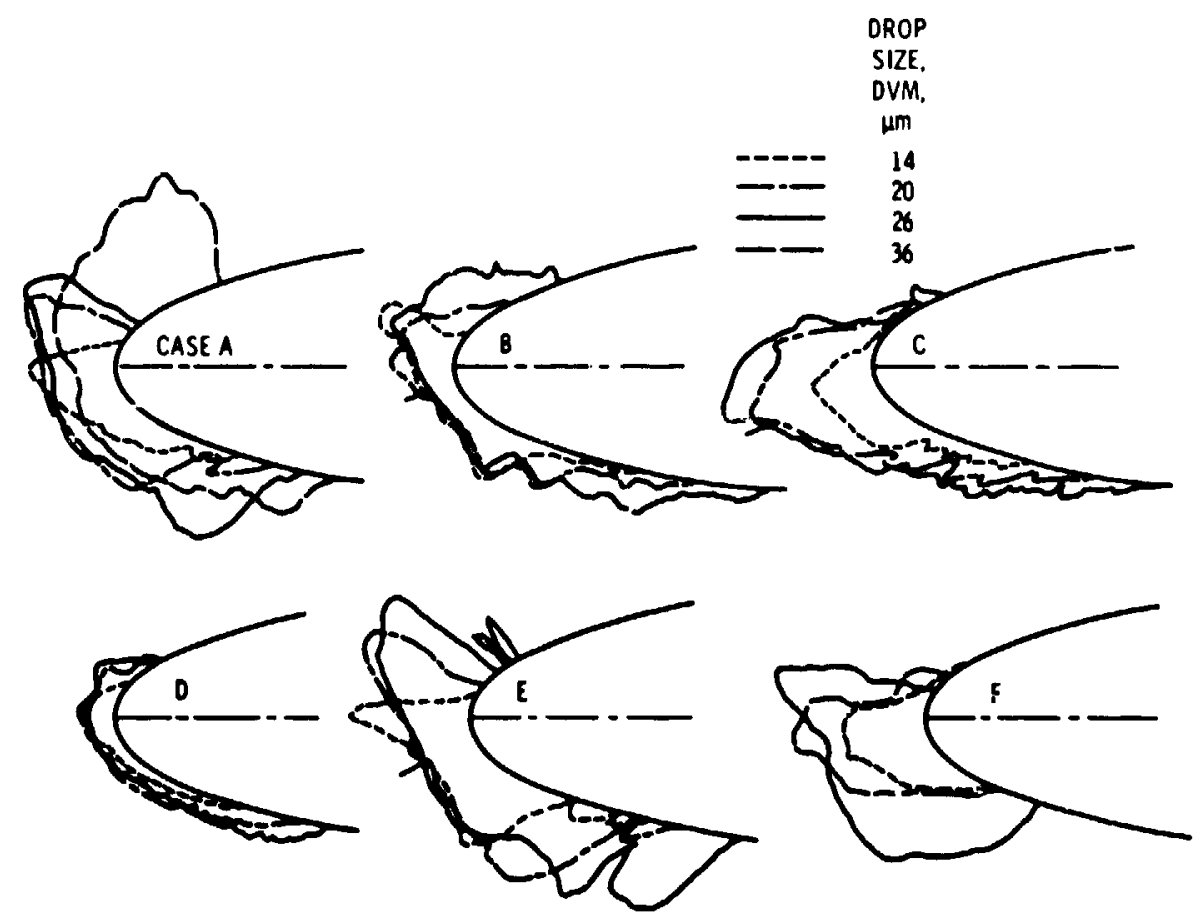

(b) ke shope.

Figure H. - Eflect of droplet size on shape and oray Airfoll. .063-m-chord 0012 airloll at so angle. 


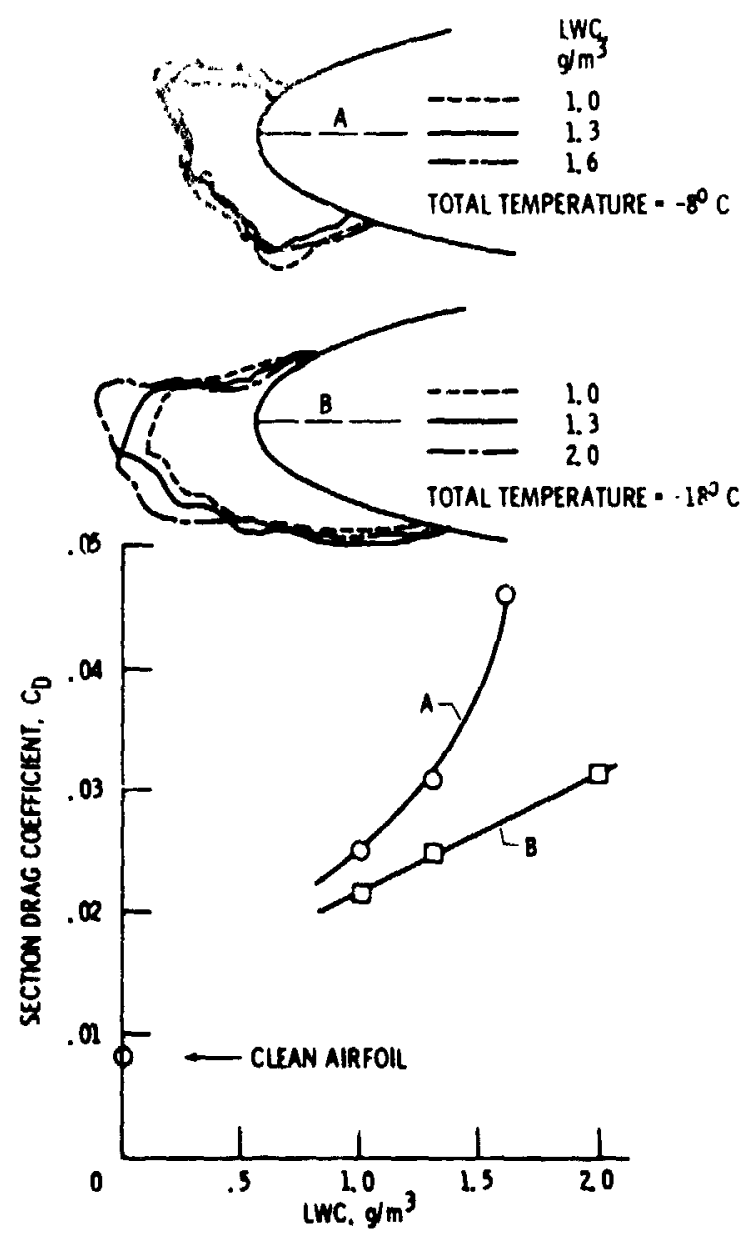

Fbure 15. - Efrect of IWC on the lee shape and section oreg Alrspod, $209 \mathrm{~km} / \mathrm{hr}$; OVM. $20 \mathrm{\mu m}$; time, $1 \mathrm{~min}$; airfoll, .53-m-chord 0012 diftoll at $P$ angle of athack 


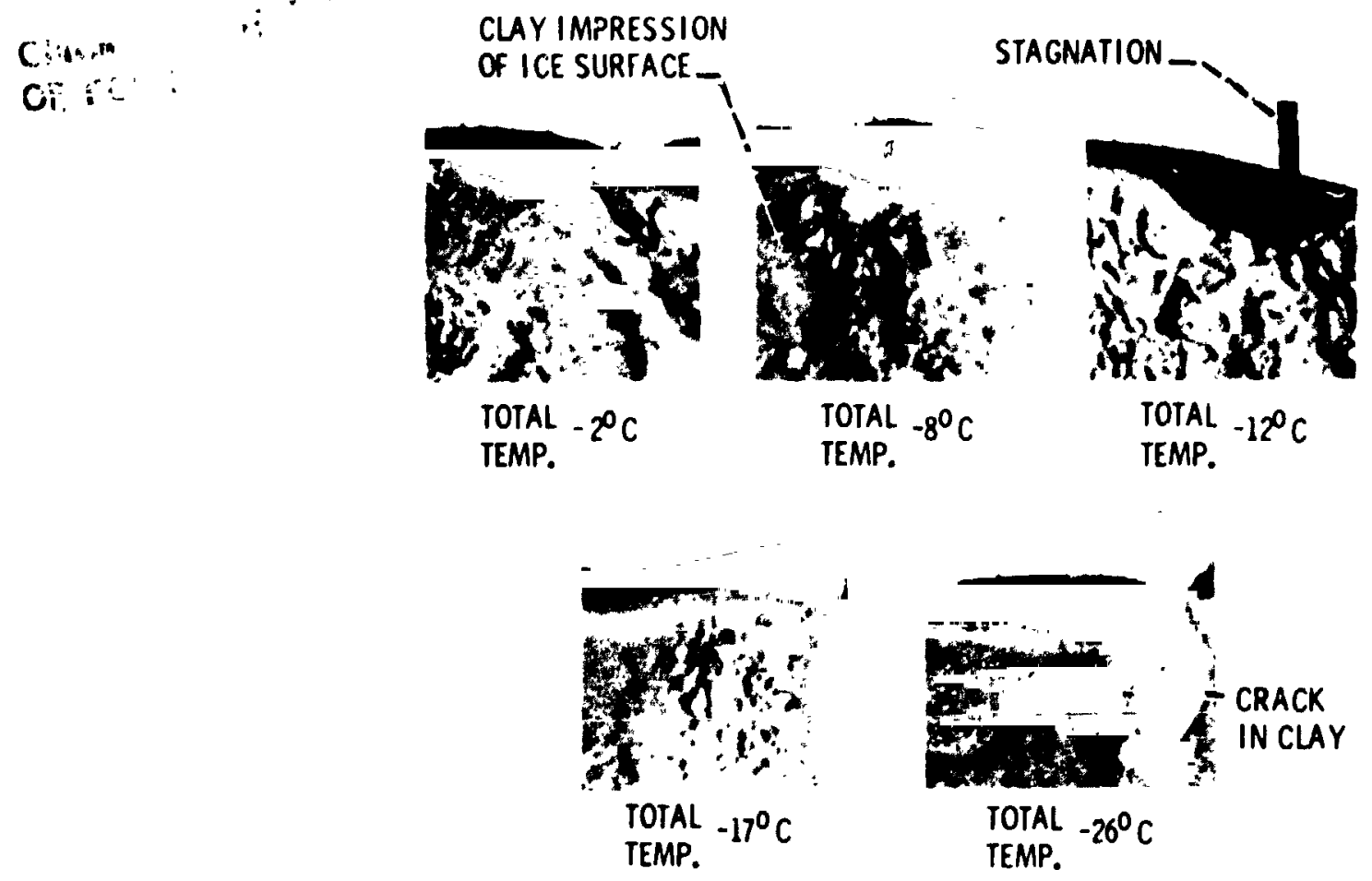

Figure 16. - Elfect of temperature on the $r^{\prime}$-aghness of the ice surface

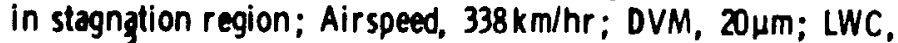
$1.05 \mathrm{~g} / \mathrm{m}^{3}$; Time, $6.2 \mathrm{~min}$. ; Airfoil, $.053 \mathrm{~m}$ chord 0012 airfoil at 4 deg. angle.

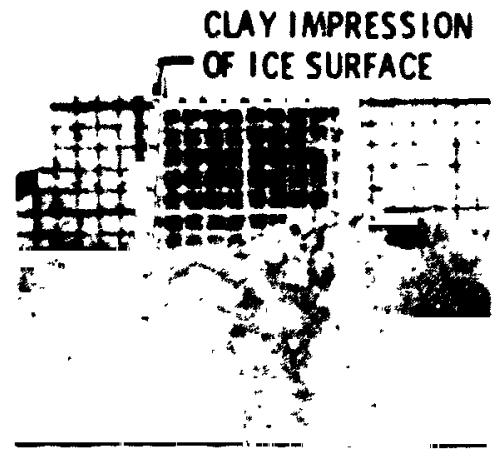

TIME 2 MIN.

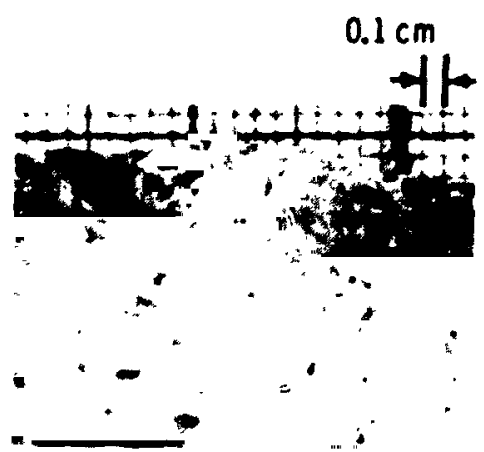

IIME 5 MIN.

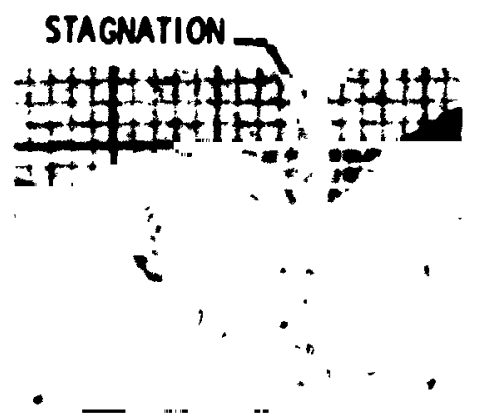

TIME 15 MIN

Figure 17. - Effect al time on the rough ness of the ice surface in stajnation region. Alirspeed, 209km/hr; Total temp. - -8C; DVM, 20um: LWC, $2.1 \mathrm{~g} / \mathrm{m}^{3}$; Airloil, . $53 \mathrm{~m}$ chord 0012 airfoil at 4 deg. angle of attack. 
Oftori:

OF FOCR

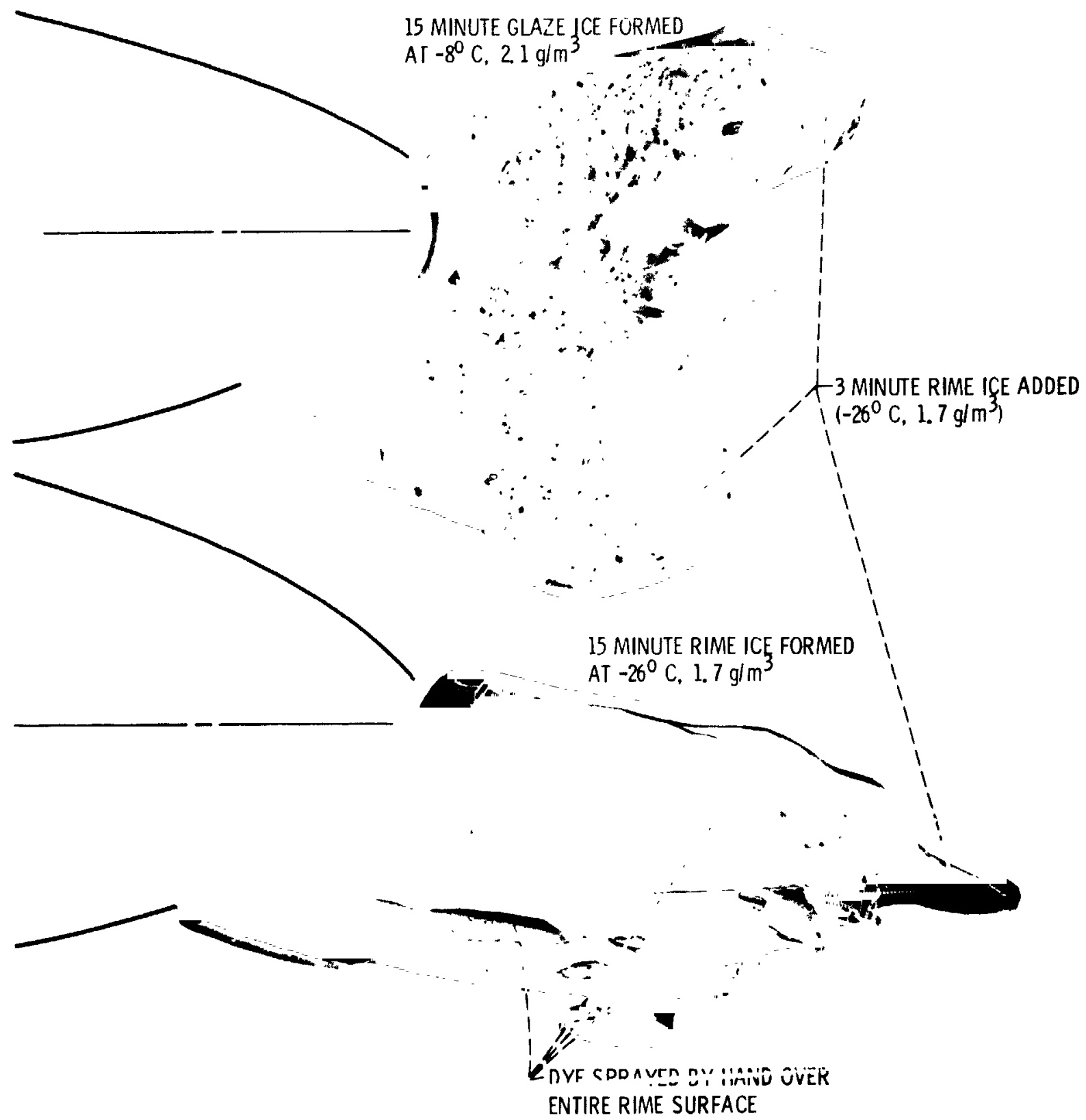

Figure 18. - The effect of the ice shape on the droplet catch. Backlighted thin ice sample of a 3 minute rime

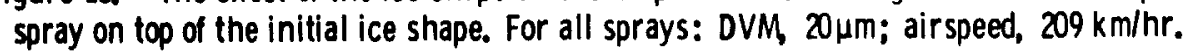




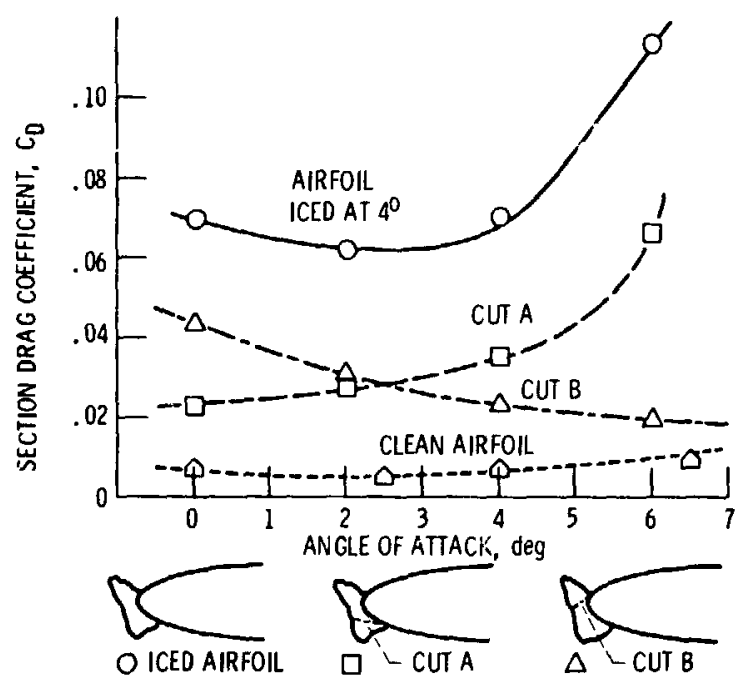

Figure 19. - Effout of partial ice removal on the drag. Conditions for the initial ice: total temperature, $-8^{0} \mathrm{C}$; airspeed, $338 \mathrm{~km} / \mathrm{hr}$; DVM, $20 \mu \mathrm{m}$; LWC, $1.05 \mathrm{~g} / \mathrm{m}$; airfoil, . $053-\mathrm{m}$-chord 0012 airfoil at $4^{0}$.

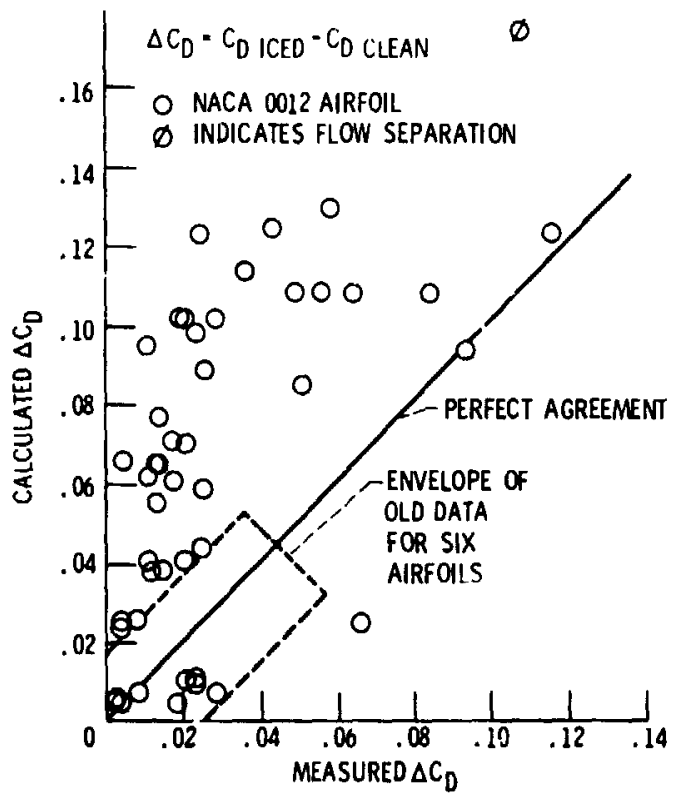

Figure 20 - Comparison of measured drag coefficient with values predicted by old correlation (ref. ll) for 0012 airfoil over a wide range of icing conditions. 


\begin{tabular}{|c|c|c|c|c|}
\hline $\begin{array}{c}\text { ICE SHAPE } \\
\text { (FROST REMOVED) }\end{array}$ & & & & \\
\hline $\begin{array}{l}\text { ICING CONDITIONS: } \\
\text { AIRSPEED } \\
\text { TEMPERATURE } \\
\text { ANGLE OF ATTACK } \\
\text { LWC } \\
\text { DVM } \\
\text { TIME }\end{array}$ & \multicolumn{2}{|c|}{$\begin{array}{c}209 \mathrm{~km} / \mathrm{hr} \\
-8^{\circ} \mathrm{C} \\
4^{0} \\
2.1 \mathrm{~g} / \mathrm{m}^{3} \\
20 \mu \mathrm{m} \\
5 \mathrm{~min}\end{array}$} & \multicolumn{2}{|c|}{$\begin{array}{c}209 \mathrm{~km} / \mathrm{hr} \\
-26^{\circ} \mathrm{C} \\
4^{\circ} \\
1.0 \mathrm{~g} / \mathrm{m}^{3} \\
12 \mu \mathrm{m} \\
5 \mathrm{~min}\end{array}$} \\
\hline $\begin{array}{l}\text { DRAG COEFFICIENT } \\
\text { AS ICE SPAN } \\
\text { IS REDUCED: }\end{array}$ & $C_{D}$ & $\begin{array}{l}\text { AMOUNT OF } \\
\text { CHANGE IN } \\
C_{\text {D }} \\
\text { PERCENT }\end{array}$ & $C_{D}$ & $\begin{array}{l}\text { AMOUNT OF } \\
\text { CHANGE IN } \\
C_{\text {R' }} \\
\text { PERCENT }\end{array}$ \\
\hline $\begin{array}{l}\text { (a) CEILING TO FLOOR }(1.8 \mathrm{~m}) \\
\text { (b) MIDDLE } 1.2 \mathrm{~m} \\
\text { (c) MIDDLE } 0.6 \mathrm{~m} \\
\text { (d) MIDDLE } 0.3 \mathrm{~m}\end{array}$ & $\begin{array}{l}0.0338 \\
.0351 \\
.0345 \\
.032\end{array}$ & $\begin{array}{c}0 \text { QREF. I } \\
3.5 \\
2.0 \\
-3.6\end{array}$ & $\begin{array}{l}0.0100 \\
.0098 \\
.0093\end{array}$ & $\begin{array}{l}0 \text { (REF.) } \\
-23 \\
-7.7\end{array}$ \\
\hline
\end{tabular}

Figure 21. - Effect of reducing the span of the ice on the measured section drag coefficient.

\begin{tabular}{|c|c|c|c|c|c|}
\hline & & & \\
\hline
\end{tabular}

Figure 22. - Effect of frost and lower surface ice feathers on the measured section drag coefficient of the NACA0012 airfoil. $\mathrm{C} \cdot 0.533 \mathrm{~m}$. (From rel. 18. ) 


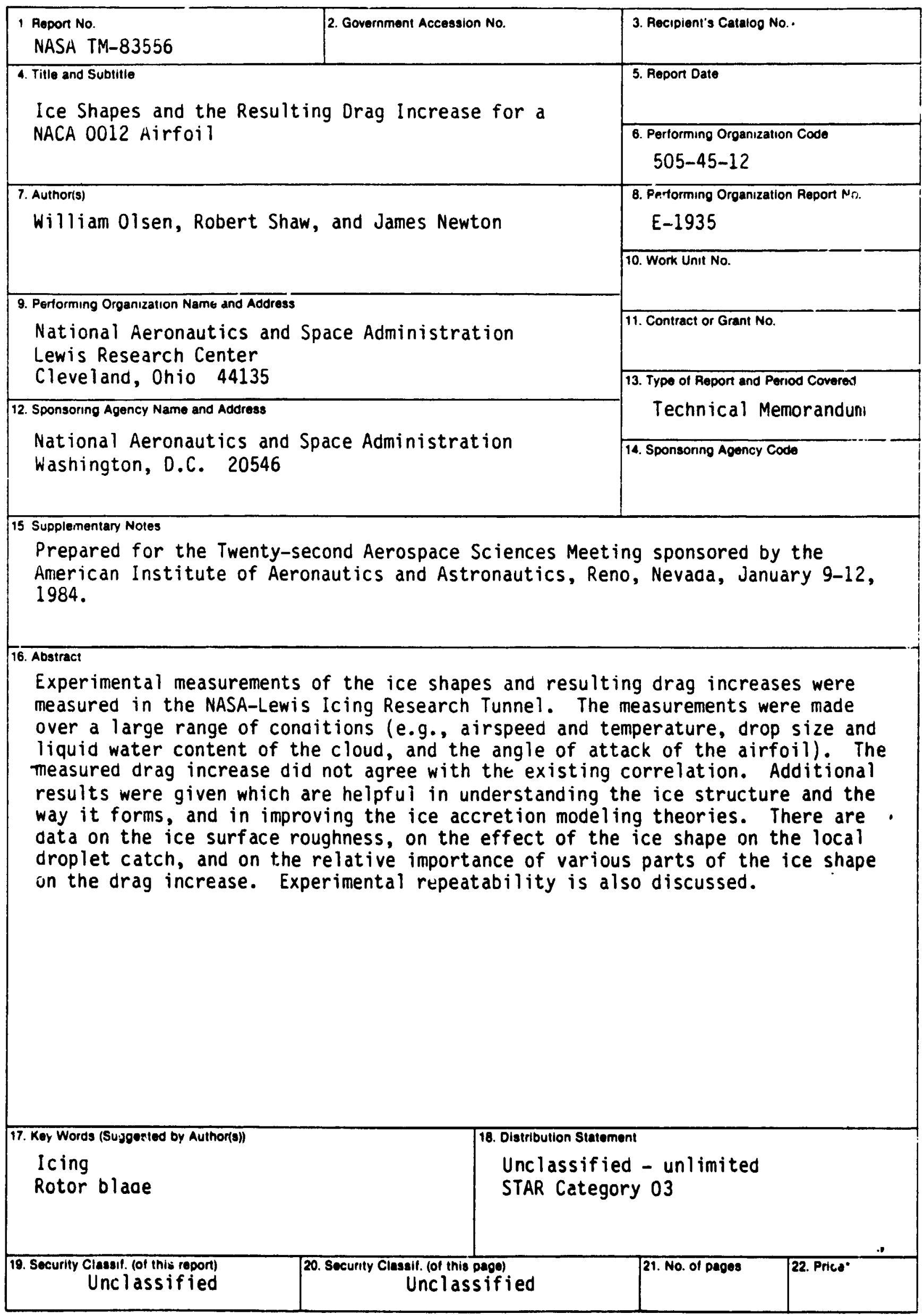

"For sale by ine National Technical Information Service, Sprıngfield, Virgınia 22161 